\title{
Dental calculus indicates widespread plant use within the stable Neanderthal dietary niche
}

\author{
Robert C. Power a, b, *, Domingo C. Salazar-García b, c, Mauro Rubini d, e, Andrea Darlas ${ }^{\text {f }}$, \\ Katerina Havarti ${ }^{g}$, Michael Walker ${ }^{\mathrm{h}}$, Jean-Jacques Hublin ${ }^{\mathrm{b}}$, Amanda G. Henry ${ }^{\mathrm{a}}$ i \\ ${ }^{a}$ Max Planck Research Group on Plant Foods in Hominin Dietary Ecology, Max Planck Institute for Evolutionary Anthropology, Deutscher Platz 6, 04103 \\ Leipzig, Germany \\ ${ }^{\mathrm{b}}$ Department of Human Evolution, Max Planck Institute for Evolutionary Anthropology, Deutscher Platz 6, Leipzig, Germany \\ ${ }^{c}$ Grupo de Investigación en Prehistoria IT-622-13 (UPV-EHU)/IKERBASQUE-Basque Foundation for Science, Vitoria, Spain \\ ${ }^{\mathrm{d}}$ Department of Archaeology, University of Foggia, Italy \\ e Anthropological Service of SABAP-RM-MET (Ministry of Culture Italy), V. Pompeo Magno 2, Rome, Italy \\ ${ }^{\mathrm{f}}$ Ephoreia of Paleoanthropology and Speleology, Greek Ministry of Culture and Sports, Ardittou 34b, 1636 Athens, Greece \\ ${ }^{g}$ Paleoanthropology, Department of Early Prehistory and Quaternary Ecology, Senckenberg Center for Human Evolution and Paleoecology, Eberhard Karls \\ University of Tübingen, Rümelinstrasse 23, Tübingen 72070, Baden-Württemberg, Germany \\ ${ }^{\mathrm{h}}$ Departamento de Zoología y Antropología Física, Universidad de Murcia, Murcia, Spain \\ ${ }^{i}$ Faculty of Archaeology, Leiden University, Leiden, The Netherlands
}

\section{A R T I C L E I N F O}

\section{Article history:}

Received 16 June 2017

Accepted 16 February 2018

\section{Keywords:}

Neanderthal diet

Dental calculus

Starches

Phytoliths

Paleodiet

\begin{abstract}
A B S T R A C T
The ecology of Neanderthals is a pressing question in the study of hominin evolution. Diet appears to have played a prominent role in their adaptation to Eurasia. Based on isotope and zooarchaeological studies, Neanderthal diet has been reconstructed as heavily meat-based and generally similar across different environments. This image persists, despite recent studies suggesting more plant use and more variation. However, we have only a fragmentary picture of their dietary ecology, and how it may have varied among habitats, because we lack broad and environmentally representative information about their use of plants and other foods. To address the problem, we examined the plant microremains in Neanderthal dental calculus from five archaeological sites representing a variety of environments from the northern Balkans, and the western, central and eastern Mediterranean. The recovered microremains revealed the consumption of a variety of non-animal foods, including starchy plants. Using a modeling approach, we explored the relationships among microremains and environment, while controlling for chronology. In the process, we compared the effectiveness of various diversity metrics and their shortcomings for studying microbotanical remains, which are often morphologically redundant for identification. We developed Minimum Botanical Units as a new way of estimating how many plant types or parts are present in a microbotanical sample. In contrast to some previous work, we found no evidence that plant use is confined to the southern-most areas of Neanderthal distribution. Although interpreting the ecogeographic variation is limited by the incomplete preservation of dietary microremains, it is clear that plant exploitation was a widespread and deeply rooted Neanderthal subsistence strategy, even if they were predominately game hunters. Given the limited dietary variation across Neanderthal range in time and space in both plant and animal food exploitation, we argue that vegetal consumption was a feature of a generally static dietary niche.
\end{abstract}

() 2018 Elsevier Ltd. All rights reserved.

\section{Introduction}

Neanderthals occupied environments drastically different from those where hominins first evolved. The ability of this hominin

\footnotetext{
* Corresponding author.

E-mail address: robert_power@eva.mpg.de (R.C. Power).
}

species to settle in diverse habitats, from the Mediterranean margin to steppic areas as cold as present-day Arctic tundra, implies that Neanderthals were successful at adapting to varied environments. In particular, their diets must have been flexible enough to allow them to thrive in these varied environments. However, some researchers have linked the disappearance of Neanderthals at the end 
of Middle Paleolithic to diets which were, relative to those of Upper Paleolithic peoples, narrower (Richards et al., 2001; Hockett and Haws, 2003, 2009; O'Connell, 2006). This idea is supported by stable isotopic and fauna data (Stiner, 1999; Richards et al., 2001; Conard et al., 2011). In this view, Neanderthal subsistence was reliant on a more restricted range of staples than that of modern humans, giving them a competitive disadvantage against Upper Paleolithic peoples.

Dietary breadth models, borrowed from the framework of behavioral ecology, have provided a means to interpret Paleolithic dietary adaptations. These models are predicated on the idea that foragers will select the foods that provide the most nutritional benefit (in calories, macro- or micronutrients) at the lowest costs, taking into account food processing requirements, within the constraints imposed by the environment (Winterhalder and Smith, 2000; Rothman et al., 2006). When the return rates for preferred foods decrease, due to climate change or population related hunting pressure, then more food types are added to the diet. A broadening diet is therefore not an adoption of an improved diet. It is just one of a number of possible responses to food scarcity that also includes intensity of food processing and technological adaptation.

Neanderthals are often interpreted as narrow spectrum foragers (Kuhn and Stiner, 2006; O'Connell, 2006; Stiner and Kuhn, 2009; Stiner, 2013). Models of Middle Paleolithic dietary ecology suggest that they hunted predominantly medium and large prime-age fauna with only infrequent use of small mammals, and aquatic and plant foods. Nitrogen stable isotope ratios indicate that they were at the top of the terrestrial food web and obtained most of their protein from medium and large-sized herbivores (Richards et al., 2000; Lee-Thorp and Sponheimer, 2006; Richards and Trinkaus, 2009; Fiorenza et al., 2015; Wißing et al., 2015). Some zooarchaeologists have argued that this diet was stable over time, with little evidence of a chronological trend towards more diverse resource use (Stiner et al., 2000; Stiner, 2013). Surviving tool repertoires show scant evidence for the investment in specialized technology for collecting plants, fish, and small mammals (Kuhn and Stiner, 2006; O'Connell, 2006; Henry et al., 2014). A low diversification in food choice and high consumption of large and medium-sized game matches evidence from site density and their genetic history that imply sparse, dispersed populations of Neanderthals that did not deplete high-ranked prey items (Stiner, 1999; Stiner and Munro, 2002; Macdonald et al., 2009; Verpoorte, 2009; Castellano et al., 2014).

This view of rigid Neanderthal diets is complicated by studies suggesting evidence for variation in their diets. Prey selected by Neanderthals varies throughout their range, often along ecological gradients. In southern regions, there is evidence for the consumption of low-ranked small game (Stiner, 1994; Blasco and Fernández Peris, 2009; Stiner and Kuhn, 2009; Hardy et al., 2013; Salazar-García et al., 2013; Fiorenza, 2015). In southern Iberia and western Italy, there is also zooarchaeological evidence of a contribution of marine resources (Stiner, 1994; Stringer et al., 2008; Zilhão et al., 2010). A preponderance of small game, including shellfish and tortoise (Testudo spp.), is also known from sites such as Kalamakia in Greece, Grotta dei Moscerini in Italy, Bajondillo Cave and Bolomor Cave in Spain and Nahal Meged in Israel (Stiner, 1994; Cortés-Sánchez et al., 2011; Blasco and Fernández Peris, 2012; Harvati et al., 2013). A study of tortoise remains at Nahal Meged showed a decrease in size due to hunting pressure and climate, beginning in the late Middle Paleolithic, suggesting that Neanderthals were collecting these foods at significant enough rates to reduce their body size (Stiner et al., 2000). In Cova del Bolomor, tortoises, rabbits and birds appear to have been frequently foraged during MIS 6 (Blasco and Fernández Peris, 2009; SalazarGarcía et al., 2013). In the warm MIS 5e interglacial, a greater proportion of small game is observed at several northern European sites despite the apparent continued dependence on large game (Gaudzinski-Windheuser and Roebroeks, 2011).

The current debate between a rigid, narrow diet and a more variable range of diets continues because most of our dietary evidence is fragmentary (Fiorenza et al., 2015). As described above, the archaeological evidence is variable, and other potential sources of information, such as ethnographic studies, offer limited information. Recent foragers in northern environments provide a poor reference for Pleistocene foragers, in part because the treeless biomes of the Pleistocene have no analogue in the modern era (Stewart, 2005). The biomass of Pleistocene grasslands far exceeded that of present day Eurasian tundra, providing a greater number of available animals for Neanderthals. We know less about the productivity of plant foods in this ecological zone (Verpoorte, 2009), but energy-rich plants were available on the steppe-tundra and throughout western Eurasia (Sandgathe and Hayden, 2003; Hardy, 2010).

Relatively little evidence of plant use is available. Most isotopic profiles conducted so far have been produced from collagen, and thus reveal little information on the consumed macronutrients other than proteins that could have been obtained from vegetable resources. Macrobotanical remains that survive in a small number of archaeological sites-e.g., Kebara Cave (Lev et al., 2005) and Douara Cave (Matsutani, 1987) in the Levant, and Gorham's and Vanguard Cave in Gibraltar (Barton et al., 1999; Gale and Carruthers, 2000)-suggest some level of plant use. The most comprehensive studies of dietary variability that incorporate plant foods stem from indirect evidence, such as dental microwear analyses, which have revealed that Neanderthals predominantly consumed meat, with a possible increased use of plants in the southern wooded parts of their range (El Zaatari et al., 2011; Fiorenza et al., 2011). The microwear of Neanderthals who inhabited cold-steppe environments resembled that of historic Fuegians who inhabited cold wet scrublands (Grine, 1986; Fiorenza et al., 2011). However, dental wear is silent on the number and types of plants consumed, or if low-ranked foods were consumed, meaning these studies create an incomplete picture of diet in different environments.

Neanderthals appear to have had more diverse diets in southern regions, possibly due to ecological variation (Stiner, 1999, 2001). Some researchers have pointed to legume assemblages from Kebara Cave (63-45 ka) and grass seed phytoliths from Amud Cave (70-55 ka), arguing that the use of more diverse resources was present already in the Middle Paleolithic (Madella et al., 2002; Lev et al., 2005). Others have studied starch and phytolith microremains trapped in dental calculus, and found that Neanderthal dental calculus from sites such as Spy and Shanidar indicate the use of date palm fruits and grass seeds in the Levant, and water lily tubers in northern Europe (Henry et al., 2011). In addition, geneticists have explored dental calculus aDNA as a source of dietary information, although plant DNA was found, its sheer rarity makes its significance hard to clarity (Weyrich et al., 2017). Despite these insights into Neanderthal use of plants, these samples are too widespread in time and space to give reasonable coverage of potential variation in Neanderthal diets. Importantly, these studies tell us little about the longevity of the Middle Paleolithic dietary niche. It is unknown if Neanderthal exploitation of plant foods broadened over the hundreds of thousands of years they occupied Eurasia in response to higher populations or milder climates, similarly to what is observed for the Upper Paleolithic and recent hunter-gatherers, or if variation is only linked to different environments. 
To explore the flexibility of Middle Paleolithic dietary patterns through environmental variation, we investigated plant consumption as recorded in dental calculus from environments with varied vegetation and differing seasonal temperatures (given as mean winter and summer temperatures). We analyzed plant microremains trapped in dental calculus from Neanderthal teeth from five archaeological sites: Vindija (Croatia), Grotta Guattari (Italy), Grotta Fossellone (Italy), Sima de las Palomas del Cabezo Gordo (Spain) and Kalamakia (Greece). These samples derive from a variety of regions and biomes across Europe: the northern Balkans, and the western, central and eastern Mediterranean (Fig. 1). We then identified microremains to examine the variety of consumed taxa. It is well established that foragers living in warmer climates and lower latitudes acquire a greater proportion of food from plants (Kelly, 1995). Some researchers have found that increased reliance on plant foods also indicates the consumption of a larger number of different plant taxa (Marean, 1997), but we found no global surveys to confirm this idea. To overcome this, we collected the number of species recorded as food plants from seven foraging populations from a variety of environments and charted the relationship between climate and the number of plants used. Once complete, we explored if Middle Paleolithic dietary breadth varied in different climatic and ecological conditions. We predicted that if Neanderthal diet was flexible, the number of plant types represented in the calculus should be greater in samples from warmer, more arboreal environments.

\section{Materials and methods}

\subsection{Sites and samples}

We collected 28 samples of dental calculus from Neanderthal teeth representing no more than 22 individuals from five sites (Table 1). The sites range between 35 and $90 \mathrm{ka}$ and represent a variety of habitats (Table 2). They range from open temperate environment at Vindija to Mediterranean mosaic woodland at Sima de las Palomas del Cabezo Gordo, and from cooler at Vindija to warmer at Kalamakia. This range reflects the bulk of environments Neanderthals occupied. Full site descriptions are provided in the Supplementary Online Material (SOM). From each site, we collected a variety of control samples, including sediments from the sites, dust on the skeletal material, and samples of the material in which the remains were stored (SOM Table S1). We also tried to sample dental calculus from the teeth of herbivorous and carnivorous fauna as an additional control and to explore if Neanderthals, like carnivores, consumed the stomach contents of herbivores (Buck and Stringer, 2014). Unfortunately, we were able to access faunal material from Vindija, Kalamakia and Sima de las Palomas del Cabezo Gordo. These samples included wolf (Canis lupus), which is mostly carnivorous but also known to consume some plant material; an indeterminate felid (cf. Panthera), cave bear (Ursus spelaeus), wild boar (Sus scrofa), an indeterminate micromammal, and deer (Dama and Cervus). These samples represent a range in dietary niches, from the purely carnivorous felid (Bocherens et al., 2011), through the wolf and bear that included increasing proportions of

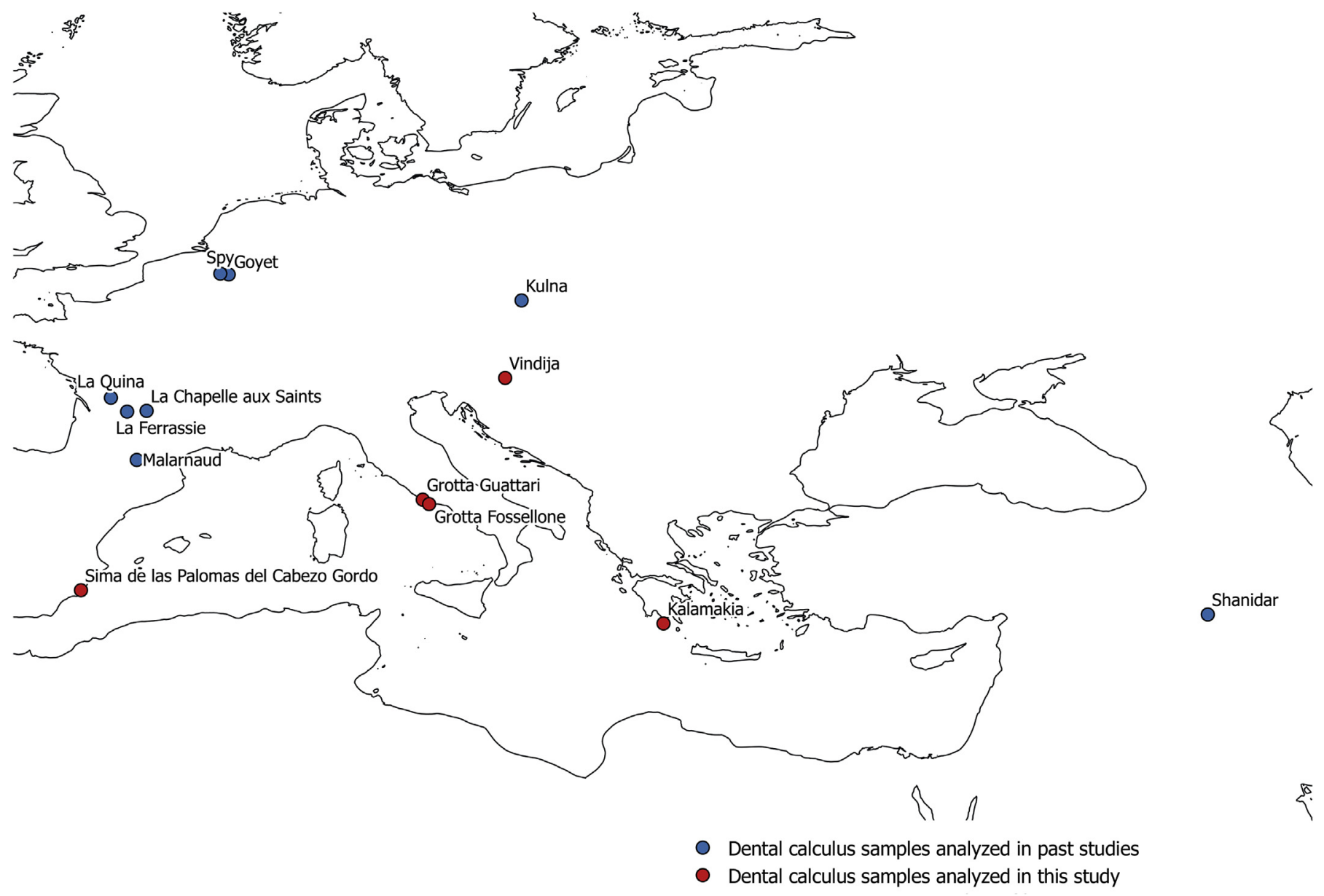

Figure 1. Map of western Eurasia with the studied sites indicated. 
Table 1

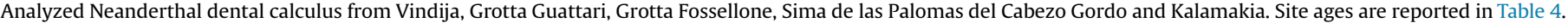
Multiple samples from the same individual are presented as a single entry. Weight unavailable for SP79, KAL 8 and SP84.

\begin{tabular}{|c|c|c|c|c|}
\hline Sample & Site & Specimen & Tooth & Weight (mg) \\
\hline Vja-13 & Vindija & 12.1 & $\mathrm{R} \mathrm{M}^{2}$ & 0.393 \\
\hline Vja-14 & Vindija & 12.2 & $\mathrm{R} \mathrm{I}_{2}$ & 0.046 \\
\hline Vja-16 & Vindija & 12.4 & $\mathrm{R} \mathrm{I}^{1}$ & 0.046 \\
\hline Vja-17 & Vindija & 12.5 & $\mathrm{R} \mathrm{C}^{1}$ & 0.045 \\
\hline Vja-18 & Vindija & 12.6 & $\mathrm{LCC}_{1}$ & 0.020 \\
\hline Vja-19 & Vindija & 12.7 & $\mathrm{LI}_{2}$ & 0.890 \\
\hline Vja-21 & Vindija & 11.39 & $\mathrm{RC}_{1}, \mathrm{R} \mathrm{M}_{1}$ & 0.502 \\
\hline Vja-23 & Vindija & 11.4 & $\mathrm{~L} \mathrm{M}_{1}$ & 0.377 \\
\hline Vja-24 & Vindija & 11.45 & $\mathrm{~L} \mathrm{M}_{3}$ & 0.672 \\
\hline Vja-26 & Vindija & 11.46 & $\mathrm{~L} \mathrm{M}^{2}$ & 0.865 \\
\hline FON1 & Grotta Fossellone & Fossellone 3 & $\mathrm{~L} \mathrm{M}_{1}$ & 0.067 \\
\hline FON2 & Grotta Fossellone & Fossellone 3 & $\mathrm{~L} \mathrm{M}_{2}$ & 0.100 \\
\hline GTN1 & Grotta Guattari & Guattari II & $\mathrm{R} \mathrm{M}_{3}$ & 0.654 \\
\hline GTN2 & Grotta Guattari & Guattari III & $\mathrm{R} \mathrm{M}_{1}$ & 0.871 \\
\hline GTN3 & Grotta Guattari & Guattari III & $\mathrm{L} \mathrm{I}_{2}$ & 0.654 \\
\hline GTN4 & Grotta Guattari & Guattari III & $\mathrm{R} \mathrm{I}_{2}$ & 0.258 \\
\hline GTN5 & Grotta Guattari & Guattari III & $\mathrm{L} \mathrm{M}_{1}$ & 0.289 \\
\hline SP45 & Sima de las Palomas del Cabezo Gordo & SP45 & $\mathrm{LP}_{3}$ & 0.080 \\
\hline SP54 & Sima de las Palomas del Cabezo Gordo & SP54 & $\mathrm{R} \mathrm{C}_{1}$ & 0.102 \\
\hline SP58a & Sima de las Palomas del Cabezo Gordo & SP58 & $\mathrm{R} \mathrm{M}_{3}$ & 0.538 \\
\hline SP78a & Sima de las Palomas del Cabezo Gordo & SP78 & $\mathrm{L} \mathrm{P}_{4}$ & 0.415 \\
\hline SP79 & Sima de las Palomas del Cabezo Gordo & SP79 & $\mathrm{L} \mathrm{I}^{1}$ & - \\
\hline SP83 & Sima de las Palomas del Cabezo Gordo & SP83 & $\mathrm{R} \mathrm{dP}_{4}$ & 0.090 \\
\hline SP84 & Sima de las Palomas del Cabezo Gordo & SP84 & M2 & - \\
\hline KAL_3 & Kalamakia & KAL 3 & $\mathrm{~L} \mathrm{M}^{3}$ & 2.866 \\
\hline KAL_5 & Kalamakia & KAL 5 & $\mathrm{LP}^{4}$ & 0.050 \\
\hline KAL_8 & Kalamakia & KAL 8 & $\mathrm{R} \mathrm{M}^{2}$ & - \\
\hline
\end{tabular}

plant foods (Pacher and Stuart, 2009), to the purely herbivorous deer. In addition to the 27 Neanderthal calculus samples from the five sites that we processed for this study, we also included previously published data from a variety of other northern European, Levantine, and southern European sites (SOM S1; Salazar-García et al., 2013; Henry et al., 2014).

\subsection{Dental calculus and control sampling}

Neanderthal teeth from each site were examined for deposits of dental calculus situated on the tooth surface in a cleaned laboratory of the institution where each specimen is curated. Deposits of dental calculus were common on teeth examined, but it was not present on all specimens. We documented the dental calculus deposits with photography before sampling. We then collected 14 samples of dental calculus from the Vindija Neanderthal teeth (levels F, G1 and G3), five from the Grotta Guattari teeth (levels G0), two from the Grotta Fossellone teeth (level 4), seven from Sima de las Palomas del Cabezo Gordo teeth (Upper Cutting level 2 and I), and three from the Kalamakia teeth (Unit III and Lower IV; Table 1). Many of the sampled teeth had a visible band of hard supragingival dental calculus, except the Iberian teeth, which were encrusted in calcium carbonate. In these samples, when possible, we took 'deep' and 'shallow' samples. 'Shallow' sediment samples were closer to the surface and likely to represent the sediment, while 'deep' ones were more likely to include calculus. The 'shallow' samples were used as a control for contamination.

The sampling surface was gently dry brushed with a disposable toothbrush to dislodge contaminants at the sampling locations. We then used a dental scalar to remove small areas of dental calculus onto creased weighing paper underlain by aluminum foil. The material collected in the paper was then transferred to a microcentrifuge tube. After sampling, we photographed the teeth and the remaining unsampled dental calculus. We then transported the samples to the Plant Foods laboratory at the Max Planck Institute for Evolutionary Anthropology (MPI-EVA).
To minimize risk of contamination from airborne modern plant material and laboratory supplies (Langejans, 2011; Crowther et al. 2014; Henry, 2014), we conducted a regime of weekly laboratory cleaning. All laboratory work surfaces were cleaned with hot water, washed with starch-free soap and with $5 \%$ sodium hydroxide $(\mathrm{NaOH})$. To assess contamination types, we additionally performed wipe tests before and after weekly cleaning to quantify starch and other contaminants. Wipe tests retrieved settled particles of the surface area $\left(74 \times 43 \mathrm{~cm}^{2}\right)$ of the laboratory positivepressure laminar flow hood used for mounting. Results of these intensive contamination control tests are found in the SOM Table S1.

\subsection{Sample preparation and mounting}

Using standard procedures (Power et al., 2014; Leonard et al., 2015), each sample was weighed and transferred to microcentrifuge tubes while in a clean laminar flow hood at the Plant Food Group Laboratories at the MPI-EVA. Each sample was then gently broken up with 1 second of micropestle use in a $1.5 \mathrm{ml}$ Eppendorf microcentrifuge tube containing 30 $\mu \mathrm{l}$ of a $25 \%$ glycerine solution to reduce sample loss due to static electricity. The samples were then centrifuged at $1691 \times \mathrm{g}$ (Heraeus MEGAFUGE 16 with TX-400 fixed Rotors) for $10 \mathrm{~min}$. These samples were mounted on glass slides and examined under brightfield and cross-polarized light on a Zeiss Axioscope microscope at $400 \times$ magnification. No decalcification treatment ( $\mathrm{HCl}$ or EDTA) was used, in order to avoid additional processing steps that might remove or destroy microremains, particularly calcium oxalates. This leaves lumps of calculus but microremains still entrapped could be easily seen by adjusting focal plane. Identifying microremains embedded in situ was considered advantageous as it provided information on their origin. Studies on the effects of grinding on starches suggest that the gentle grinding used in this sample preparation method would have little impact on starches (Henry et al., 2009). 
Table 2

Paleoenvironment reconstructions for each specimen used in this study.

\begin{tabular}{|c|c|c|c|c|c|c|c|}
\hline \multirow[t]{2}{*}{ Site } & \multirow[t]{2}{*}{ Specimen } & \multirow[t]{2}{*}{ Age (ka cal BP) } & \multirow[t]{2}{*}{ Tree $_{\text {cover }}{ }^{b}$} & \multicolumn{2}{|c|}{ Paleotemperature $^{c}$} & \multirow[t]{2}{*}{$\mathrm{ET}^{\mathrm{d}}$} & \multirow[t]{2}{*}{ Reference } \\
\hline & & & & December-February & June-August & & \\
\hline Vindija & 12.1 & 34.3 & open & -8 & 20 & 12.22 & 1 \\
\hline Vindija & 12.2 & 34.3 & open & -8 & 20 & 12.22 & 1 \\
\hline Vindija & 12.4 & 34.3 & open & -8 & 20 & 12.22 & 1 \\
\hline Vindija & 12.5 & 34.3 & open & -8 & 20 & 12.22 & 1 \\
\hline Vindija & 12.6 & 34.3 & open & -8 & 20 & 12.22 & 1 \\
\hline Vindija & 12.7 & 34.3 & open & -8 & 20 & 12.22 & 1 \\
\hline Vindija & 11.39 & 45.5 & open & -8 & 20 & 12.22 & 1 \\
\hline Vindija & 11.45 & 45.5 & open & -8 & 20 & 12.22 & 1 \\
\hline Vindija & 11.46 & 45.5 & open & -8 & 20 & 12.22 & 1 \\
\hline Vindija & 11.4 & 45.5 & open & -8 & 20 & 12.22 & 1 \\
\hline Grotta Guattari & Circeo 2 & 55 & open & -4 & 16 & 11.71 & 1 \\
\hline Grotta Guattari & Circeo 3 & 67 & open & -6 & 16 & 11.6 & 1 \\
\hline Grotta Fossellone & Fossellone 3 & 70 & open & -6 & 16 & 11.6 & 1 \\
\hline Kalamakia & KAL 3 & 89.5 & open & 4 & 20 & 13.33 & 1 \\
\hline Kalamakia & KAL 5 & 62 & open & 5.9 & 18.45 & 13.29 & 1 \\
\hline Kalamakia & KAL 8 & 62 & open & 5.9 & 18.45 & 13.29 & 1 \\
\hline Sima de las Palomas & SP45 & 50 & closed & 4 & 20 & 13.33 & 1 \\
\hline Sima de las Palomas & SP50 & 50 & closed & 4 & 20 & 13.33 & 3 \\
\hline Sima de las Palomas & SP53 & 50 & closed & 4 & 20 & 13.33 & 3 \\
\hline Sima de las Palomas & SP54 & 50 & closed & 4 & 20 & 13.33 & 1 \\
\hline Sima de las Palomas & SP58 & 50 & closed & 4 & 20 & 13.33 & 1 \\
\hline Sima de las Palomas & SP60 & 50 & closed & 4 & 20 & 13.33 & 3 \\
\hline Sima de las Palomas & SP68 & 50 & closed & 4 & 20 & 13.33 & 3 \\
\hline Sima de las Palomas & SP74 & 50 & closed & 4 & 20 & 13.33 & 3 \\
\hline Sima de las Palomas & SP78 & 50 & closed & 4 & 20 & 13.33 & 1 \\
\hline Sima de las Palomas & SP79 & 50 & closed & 4 & 20 & 13.33 & 1 \\
\hline Sima de las Palomas & SP83 & 50 & closed & 4 & 20 & 13.33 & 1 \\
\hline Sima de las Palomas & SP84 & 50 & closed & 4 & 20 & 13.33 & 1 \\
\hline Sima de las Palomas & SP88 & 50 & closed & 4 & 20 & 13.33 & 3 \\
\hline Sima de las Palomas & SP100 & 50 & closed & 4 & 20 & 13.33 & 3 \\
\hline Kůlna & Kůlna 1 & 50 & open & -8 & 16 & 11.5 & 2 \\
\hline Goyet & Goyet VII & 40.5 & open & -8 & 12 & 10.57 & 2 \\
\hline La Chapelle-aux-Saints & Chapelle 1 & 57 & open & -4 & 12 & 10.67 & 2 \\
\hline Malarnaud & Malarnaud 1 & 75 & mixed & 0 & 12 & 10.8 & 2 \\
\hline La Ferrassie & LFI & 39 & closed & 0 & 12 & 10.8 & 2 \\
\hline La Ferrassie & LFII & 39 & closed & 0 & 12 & 10.8 & 2 \\
\hline La Quina & Quina V & 64 & mixed & -0.55 & 12.65 & 11 & 2 \\
\hline Spy & Spy 2 & 36.5 & open & -6 & 14 & 11.14 & 2 \\
\hline Spy & Spy 2 & 36.5 & open & -6 & 14 & 11.14 & 2 \\
\hline Spy & Spy 1 & 36.5 & open & -6 & 14 & 11.14 & 2 \\
\hline Spy & Spy 1 & 36.5 & open & -6 & 14 & 11.14 & 2 \\
\hline Shanidar & Shani III & 48 & closed & 2 & 25 & 13.87 & 2 \\
\hline Shanidar & Shani III & 48 & closed & 2 & 25 & 13.87 & 2 \\
\hline Shanidar & Shani III & 48 & closed & 2 & 25 & 13.87 & 2 \\
\hline
\end{tabular}

a Site age is calculated by using the mean of the calendric age range.

b Tree cover is calculated with pollen and fauna data.

c Paleotemperature is calculated from the Stage Three Project dataset (van Andel and Davies, 2003).

${ }^{\mathrm{d}}$ ET = effective temperature (which is a measure of biologically relevant temperature).

e References: 1 = this study; 2 = Henry et al. (2014); 3 = Salazar-García et al. (2013).

\subsection{Identification and classification}

We photographed and described recovered microremains using the international nomenclature codes (Madella et al., 2005; ICSN, 2011). Phytoliths were classified into conventional morphotypes, while we developed types to classify other microremains based on shared morphology. Starches were classified into 23 types according to size, shape, the presence and prominence of lamellae, hilum morphology, formation characteristics (i.e., simple or compound), cross features, cracks and other surface features (SOM Table S2). Many of these types were considered redundant for identification purposes (e.g., types 17, 18 and 19; Table 3).

It is well known that some plants, such as Triticeae, produce starches with more than one distinct starch morphology; when this was documented, both morphologies were treated as one type (Peng et al., 1999). However, not all taxa are as well understood as Triticeae, and therefore it is possible for these less well-researched plants that several types may all have originated from a single taxon, or one type may be common to several taxa. Unlike starches, phytolith morphology has internationally classified codes and phytolith morphotype multiplicity is fairly well understood (Madella et al., 2005). For example, several phytolith types (shortcell, bulliform and psilate) may all represent a single species of grass. When possible, we identified the types to the most precise taxonomic level possible, usually family or genus (SOM S1 and Table S1). When possible, we scanned for potentially informative microremain damage such as phytolith weathering, partial starch gelatinization and other forms of heat damage (SOM Table S1). We found dry heat alteration to be a damage pattern diagnostic of starch contaminants from starch-free nitrile laboratory gloves.

\subsection{Taphonomic biases}

Different processes may affect the preservation of different microremain types unevenly. Both starch and phytolith preservation qualities vary according to species but methods have not yet 
Table 3

Counted microremains and their assigned minimum botanical unit.

\begin{tabular}{|c|c|c|c|}
\hline \multicolumn{2}{|l|}{ Starches } & \multicolumn{2}{|l|}{ Phytoliths } \\
\hline Type & Minimum botanical unit & Type & Minimum botanical unit \\
\hline Type 1 & Type 1 starch & long-cell psilate & Poaceae \\
\hline Type 2 & Type 2 starch & l-c verrucate (non-generic type) & Celtis/Boehmaria/Morus or Urtica \\
\hline Type 3 & Starchy seed producer type 1 & l-c wavy & Poaceae \\
\hline Type 4 & USO starch & l-c sinuous & $C_{3}$ Poaceae \\
\hline Type 5 & Starchy seed producer type 2 & Polylobate & $\mathrm{C}_{3}$ Poaceae \\
\hline Type 6 & Type 6 starch & Trichome & Poaceae \\
\hline Type 8 & Legume starch & Rondel & $\mathrm{C}_{3}$ Poaceae \\
\hline Type 8 & Type 8 starch & Bulliform fan & Poaceae \\
\hline Type 9 & Type 9 starch & Bulliform Parallelepipedal & Poaceae \\
\hline Type 10 & Type 10 starch & Monocot hair & Monocot \\
\hline Type 11 & Type 11 starch & Cylindroid & Conifer/dicot \\
\hline Type 12 & Type 12 starch & Dicot hair & Dicot \\
\hline Type 13 & Type 13 starch & Globular sinuate/rugulate & Dicot \\
\hline Type 14 & Type 14 starch & Ellipsoid rugulate & Dicot \\
\hline Type 15 & Triticeae & Parallelepipedal & Dicot \\
\hline Type 16 & Type 16 starch. Hard endosperm starch. & Parallelepipedal thick & Dicot \\
\hline Type 17 & Redundant starch & Parallelepipedal elongate psilate & Dicot \\
\hline Type 18 & Redundant starch & Parallelepipedal thin rounded ends & Dicot \\
\hline Type 19 & Redundant starch & Multicellular long-cells & Monocot \\
\hline Type 21 & Black bindweed (Cf. Fallopia sp.) & Multicellular polyhedrons & Dicot leaf \\
\hline Type 22 & cf. Lilium sp. & Spheroid granulate & Non Poaceae \\
\hline Type 23 & Redundant starch & Mesophyll & Dicot leaf \\
\hline Other & Redundant starch & Indet. Multicell & Plant \\
\hline Partially gelatin., large ovoid & Redundant starch & Indet. Hair & Plant \\
\hline \multirow[t]{3}{*}{ Pos/Dmg } & Redundant starch & Epidermal & Dicot leaf \\
\hline & & Plate & Dicot leaf/fruit \\
\hline & & Calcium oxalate & Plant \\
\hline
\end{tabular}

been developed to control for this in dental calculus assemblages (Lu, 2000; Cabanes and Shahack-Gross, 2015; Power et al., 2015b). Food processing may also alter microremain content of plants. Different mastication patterns could potentially expose starch to varying levels of salivary amylase and influence starch survival. Cooking, (if widely practiced by Neanderthals) is expected to reduce starch content through gelatinization, but does not eliminate starch grains nor prevent them from entering dental calculus (Leonard et al., 2015). It is possible that starch could enter the mouth through the consumption of stomach contents (chyme). Given that many prey (ruminant and hindgut fermenter) can hydrolyze starch in their stomachs, we should not expect to see many starches entering human dental calculus from the consumption of chyme, since most will have been already degraded (Owens et al., 1986). Phytoliths are often concentrated in the skin and husks of edible plants and food processing often reduces phytolith content of human food. However, herbivore chyme is probably rich in phytoliths, as phytoliths are preserved well in low $\mathrm{pH}$ environments (Madella and Lancelotti, 2012). An abundance of phytoliths and few starches in calculus may suggest consumption of stomach contents rather than direct consumption of plants.

\subsection{Converting microremain diversity into measures of dietary breadth}

Estimating dietary breadth from animal and plant remain assemblages is a major challenge in archaeological research (Grayson and Delpech, 1998). Until recently, there were no data on whether dental calculus could in any way reflect dietary breadth. Fortunately, recent experimental studies have shown that dental calculus assemblages can reflect a significant amount of dietary breadth and have laid a foundation on which to base expectations (Leonard et al., 2015; Power et al., 2015b).

Once we identified the microremains, we examined the total number of microremains per $\mathrm{mg}$, but this was not ideal as it revealed little about diversity of types. Then we explored the number of microremain types and the Menhinick's index and
Menhinick's index per mg of calculus. Menhinick's index is a richness metric common in ecological studies, and is the ratio of the number of taxa to the square root of sample size (Magurran, 2004). However, these metrics have major limitations as many starch and phytoliths types may be produced by the same plant. Furthermore, many starches and phytoliths are non-diagnostic, and among those that are diagnostic, they may indicate only broad categories such as dicot.

Therefore, to complement and refine this metric, we lumped all types that could be produced by one plant or plant part together. We call this standardized sum a minimum botanical unit (MBU; Table 3). MBUs may be individual plant taxa or plant parts. For example, a sedge cone phytolith, a chloridoid saddle phytolith and a Triticeae lenticular starch are three separate MBUs, while a Triticeae lenticular starch and a dendritic long-cell from Triticeae would be lumped together into one MBU (Table 3). The results of this novel approach were further standardized by combining it with a Menhinick's index by dividing the MBU by the square root of the total number of starch and phytoliths. Then with the MB-Menhinick's sums we calculated other measures that may provide quantitative information about the assemblage. We also prepared ratios that are phytolith-specific for inferring phytolith producers, such as the monocot/dicot phytolith ratio, which may indicate contribution of grasses, sedges and other monocots versus the contribution of dicots; and the variable/consistent morphology ( $\mathrm{v} /$ c) phytolith ratio, which indicates taxon (shown in SOM Table S2).

\subsection{Climate and the number of consumed plant species in the ethnographic record}

It is long established that the percent of diet derived from plants and terrestrial meat is strongly related to climate (Kelly, 1995), and it is expected that this applies to plant species used as well (Ichikawa and Terashima, 1996). Thus, we envisaged that there is a strong relationship between climate and the taxonomic breadth of plant food use in forager societies. Foragers in grassland environments are known to follow this pattern (Marean, 1997). A second 
major aspect of this study was examining the link between the dietary reliance on plant foods and the number of different types of plant taxa in a variety of environments, as it might be possible that ancient foragers might be highly reliant on plant foods but consume only a small number of taxa. The study aimed to provide verification that recent foragers, who rely on a greater amount of plant food, gather a greater range of plant species than foragers who use fewer plants. Due to the lack of non-grassland datasets on the number of plant species consumed by foragers, we tested if there is a relationship by plotting number of plant species documented as food items in ethnographic forager diets of the Labrador Inuit, Yupik, Aleutians, Ona, Ojibwa, Hadza, Alyawara, !Kung and Baka (Table 4; Fig. 2; Smith, 1932; Ager and Ager, 1980; O'Connell et al., 1983; Hattori, 2006; Veltre et al., 2006; Marlowe, 2010; Clark, 2012; Berihuete-Azorín, 2013; Crittenden and Schnorr, 2017). Although the data are sparse, the slope highlights that in warm climates, where plant foods are more important, foragers exploit a higher number of species. If Neanderthals behaved like modern humans, then we should also expect a climate-based variation in the number of plant species they consumed.

\subsection{Paleotemperature and paleoenvironment reconstruction}

To explore whether the number of plant foods in Neanderthal diets varied according to the habitat in which they lived, we needed detailed climatic (temperature) and environmental (tree-cover) reconstructions of each of the investigated sites. For the climate, we used simulations for western Eurasia created as part of the Stage Three Project (van Andel and Davies, 2003). This project quantified climatic variables during much of the range of the last glaciation from 59 up to $24 \mathrm{ka}$, and generated four regional model simulations: MIS 3 warm climatic event, MIS 3 cold climatic event, the extremely cold Last Glacial Maximum (LGM), and finally a modern climatic model. These simulations may also be used to model conditions in other periods such as MIS 4, and are commonly used for this purpose (e.g., Aiello and Wheeler, 1995; Wales, 2012). Unfortunately, these models cannot account for third order climate fluctuations that occurred within these phases. However, when each simulation is examined with each Neanderthal site, we see that the variation in temperatures is driven more by the site's latitude and longitude than by the specific climatic period. Therefore, despite being relatively coarse-grained, these models allow us to quantify temperature variation. As more up-to-date simulations are available for the LGM, when predicting MIS 4 conditions, we used Community Climate System Model 4 (CCSM4) with 2.5 min resolution (Hijmans et al., 2005).

These simulations of temperature can be made more ecologically relevant by calculating effective temperature, a climatic predictor that evens out seasonal temperature variation. This powerful measure has been used to explain why recent forager subsistence

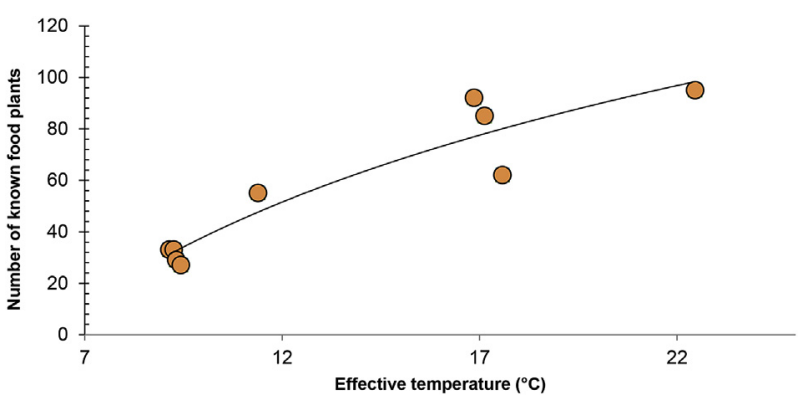

Figure 2. The relationship between warmer environments and effective temperature. Although only a limited amount of data are available, our survey includes samples from polar, temperate, tropical and arid climates. Data available in Table $4 . \mathrm{R}^{2}=0.885$.

varies latitudinally (Bailey, 1960; Binford, 2001). Effective temperature is based on three constants: the minimum mean temperature $\left(18{ }^{\circ} \mathrm{C}\right.$ ) that supports tropical plant communities (a 365 day growing season), the minimum temperature $\left(10^{\circ} \mathrm{C}\right)$ at the start of the growing season at the zonal boundary of polar and boreal environments, and the minimum temperature $\left(8^{\circ} \mathrm{C}\right)$ at the beginning of the growing season (Binford, 1980, 2001). Effective temperature (MET) is computed as follows:

$\mathrm{ET}=[(18 * \mathrm{MST})-(10 * \mathrm{MWT})] /(\mathrm{MST}-\mathrm{MWT}+8)$

where MST is mean temperature of the warmest month and MWT is mean temperature of the coldest month.

The Stage Three Project supplied mean temperature $\left({ }^{\circ} \mathrm{C}\right) 2 \mathrm{~m}$ above ground level. We matched plots of each simulation to the climatic phases in our sample set (Table 5), and we collected relevant values from each simulation plot and then calculated effective temperature for each hominin sample (Table 5).

To reconstruct the environment surrounding each site, we assessed tree cover using all published data on past habitats that existed at each site. We used investigations of macromammals, micromammals and pollen that record paleovegetation at different scales from local and regional studies to classify each environment. Based on the prevalence of tree cover, we assigned each sample as coming from open, mixed or closed habitats (Table 2). See each site paragraph in the SOM S1 for each designation.

\subsection{Statistical analyses}

To explore the relationships among environment, trends in foraging breadth, and microremains found in our samples and those from previous studies (SOM Table S3; Salazar-García et al., 2013; Henry et al., 2014), we fitted a random effect negative binomial model with likelihood ratio tests, using the glmer.nb function of the R package lme4 (Bates et al., 2013). We chose this negative binomial

Table 4

Relationship between effective temperature and the number of taxa in the diet of recent foragers.

\begin{tabular}{|c|c|c|c|c|c|}
\hline Group & Region & Effective temperature $\left({ }^{\circ} \mathrm{C}\right)$ & Plant dependence $(\%)^{\mathrm{a}}$ & Number of food plants & Citation \\
\hline Labrador Inuit & NE Canada & 9.149 & 0.01 & 33 & Clark, 2012 \\
\hline Aleutian & W Alaska & 9.258 & 1 & 33 & Veltre et al., 2006 \\
\hline Yupik & W Alaska & 9.320 & 1 & 29 & Ager and Ager, 1980 \\
\hline Ona & S Argentina and Chile & 9.436 & 5 & 27 & Berihuete-Azorín, 2013 \\
\hline Ojibwe $^{\mathrm{b}}$ & Canada, United States border & 11.395 & 11 & 55 & Smith, 1932 \\
\hline Alyawara & Central Australia & 16.867 & 65 & 92 & O'Connell et al., 1983 \\
\hline !Kung & S Africa & 17.131 & 67 & 85 & Crittenden and Schnorr, 2017 \\
\hline Hadza & E Africa & 17.586 & 60 & 62 & Marlowe, 2010 \\
\hline Baka & Cameroon & 22.463 & 85 & 95 & Hattori, 2006 \\
\hline
\end{tabular}

a Estimate of vegetal intake based on Binford forager dataset (Binford, 2001; Binford and Johnson, 2006; Kirby et al., 2016).

b Grouping averaged plant food and climate values from North Albany Ojibwa, Rainy River Ojibwa, Eastern Ojibwa, Round Lake Ojibwa and Wegamon Ojibwa. 
Table 5

Stage 3 Project simulations used to predict average summer and winter temperatures experienced by each Neanderthal (Wales, 2012).

\begin{tabular}{lll}
\hline Interval & \multicolumn{1}{c}{ Phase } & Simulation model used \\
\hline MIS 5d & Early Glacial Stadial Phase & Warm \\
MIS 5c & Early Glacial interstadial Phase & Warm \\
MIS 5b & Early Glacial Stadial Phase & Warm \\
MIS 5a & Early Glacial Warm Phase & Warm \\
MIS 4 & Transitional Phase & Warm \\
MIS 4 & First Glacial Maximum & Last Glacial Maximum \\
MIS 3 & Stable Warm Phase & Warm \\
MIS 3 & Transitional Phase & Warm \\
MIS 3 & Early Cold Phase & Cold \\
\hline
\end{tabular}

model because it is appropriate for count data that, like ours, is not normally distributed, and instead is skewed towards zero. We did not try to consider the potential effects of age at death or different age classes or sexes, as often this information is not available.

To calculate approximate sample size needed, we used Poisson regression power analysis in GPower 3.1 (Demidenko, 2007; Faul et al., 2009). The duration (defined as 'Mean exposure') $2.666{ }^{\circ} \mathrm{C}$, as the dataset as a whole varies by $2.66{ }^{\circ} \mathrm{C}$ with two tails, with a 'Base rate $\exp (\beta 0)$ ' that is estimated to be 5.75 . Based on the results from the modern foragers (Fig. 2), we estimated a $12.6 \%$ increase in MBUs for every $1{ }^{\circ} \mathrm{C}$ of effective temperature and we assigned a power of 0.85 at $\alpha=0.05$. The resulting simulation revealed mean power values of 0.856 for a sample size of 42 , although less than our sample size of 58 it is more than the number of samples from individual Neanderthals (37).

To proceed with the model, we collated multiple samples from each individual, and for which the recovered microremains were assigned to specific types. If any dental calculus samples produced no microremains, they were included as zero values. Our full model tested whether the number of MBUs was an effect of effective temperature, and the presence of tree cover at the site. We included the chronological age of the specimen as a control predicator. We prepared the data by z-transforming age and effective temperature. The site and analyst (R.C.P. and A.G.H.) were treated as random intercept terms. To test the significance of the full model, it was compared with a null model excluding fixed effects of effective temperature, age of each fossil specimen, and tree cover. Variance inflation factors (VIF) were derived, to assess collinearity, from a standard linear model minus random effects and offsets. Variance inflation factors indicated that collinearity was not an issue (largest VIF $=1.26$ ), but leverage suggests that potential influential cases exist. We tested model stability by excluding levels of the random effects (the random intercepts) one by one from the data set, running the full model and comparing the results with those from the original model that suggest no highly influential cases. To allow for the possibility of mixing between layers F, G1 and G3 in Vindija Cave, we built an identical model except that we recoded the samples from F and G1 as coming from G3. We performed similar procedures for removing overdispersion on this model $\left(\chi^{2}=42.574, \mathrm{df}=50\right.$, dispersion parameter $\left.=0.851\right)$ and ensuring VIF was not an issue (largest VIF $=1.331$ ).

\section{Results}

\subsection{Contamination controls}

Vindija Cave We collected some samples of faunal calculus, as well as adhesives used to hold Vindija tooth 11.39 (SOM Table S1).
Microremains were found on the faunal calculus samples. These included small non-diagnostic starches on all three taxa (wolf, bear, and cat), and a number of phytoliths on wolf and bear (SOM Table S1). The number of microremain types is far lower than that seen in Neanderthal calculus samples. Of the microremains, some can be identified as not representing intentional diet (Triticeae on wolf), while others likely reflect dietary behavior, as they are consistent with the diets of these species (Pacher and Stuart, 2009). Present-day wolves consume plant matter, and plants may comprise up to $40 \%$ of their food intake in certain seasons (Meriggi et al., 1991). European wolves especially favor fruit, but wolves may also consume plants in stomach contents or intentionally consume grass to smooth digestion or ease parasite discomfort (Murie, 1944; Stahler et al., 2006). Two control samples of mandible adhesive revealed 56 contaminant starches, but nearly all of these were highly diagnostic, heavily damaged potato starch. These starches are morphologically distinct from those in the Neanderthal dental calculus samples (SOM Table S1).

Grotta Guattari and Grotta Fossellone We took a variety of control samples, though not all preferred control types (e.g., faunal teeth) were available. Most controls were samples of adhesives used to bond bone, or washes of distilled water taken from the surfaces of the sampled mandibles. These contamination assays produced no or few microremains, and where microremains were found they showed a narrow range of types (Fig. 3; SOM Table S1). We found that these contaminating grains appeared distinct and usually occurred as starch aggregates, unlike more damaged and isolated starch in dental calculus samples (SOM Table S1). A Triticeae grass seed starch aggregate (type 20) was found in controls 2e and Fon3. None of this type of aggregate was found in the Neanderthal samples.

Sima de las Palomas del Cabezo Gordo In addition to controls (non-worked stone from archaeological strata, carnivore dental calculus, and packing cotton) published in Salazar-García et al. (2013), we sampled other packing material used to store hominin remains, as well as sediment found attached to hominin teeth. One sediment sample produced a single isolated subspherical starch. These results show a very low rate of background starch and phytoliths.

Kalamakia We took fauna control samples from the Kalamakia assemblage from wild boar, deer, and wild goat. These contamination controls exhibited low numbers of microremains, (Fig. 3; SOM Table S1). We found that these samples contained limited numbers of monocot and dicot phytoliths and plant tissue from grasses and dicots. All microremains are consistent with herbivore diets (SOM Table S1). 


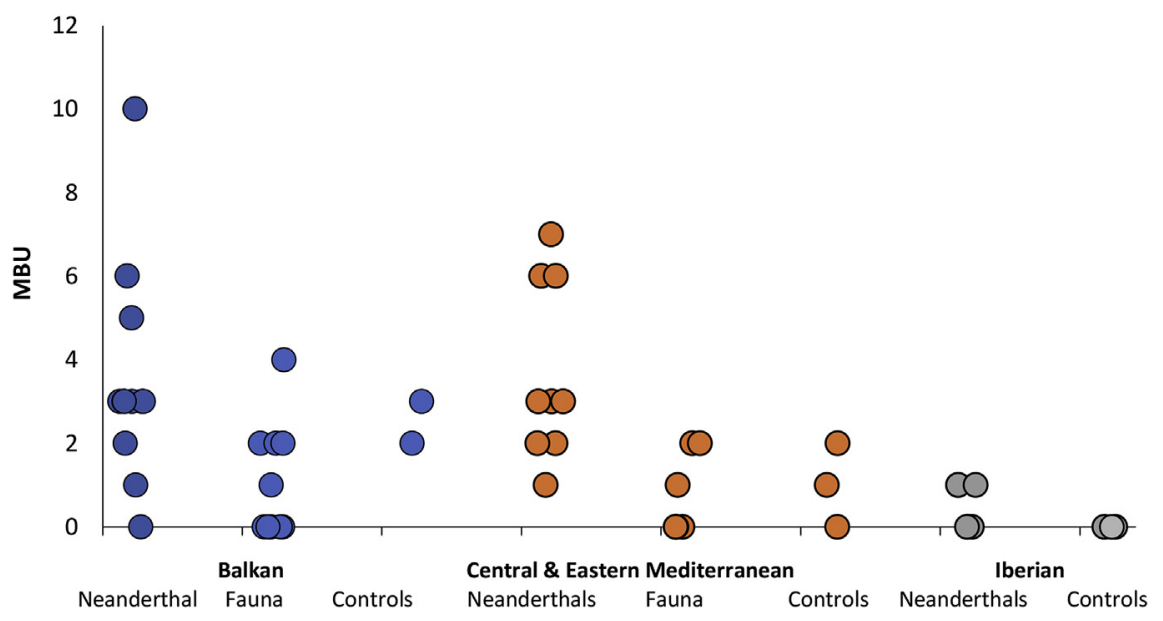

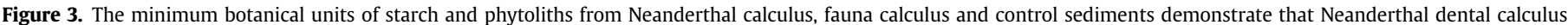
samples show a distinct signal indicating they reflect hominin diet. Each circle represents an individual sample.

\subsection{Dental calculus microremain assemblages and dietary breadth}

Vindija Cave We collected calculus from six isolated teeth and five in situ teeth (catalogue numbers listed in Table 1). Isolated teeth comprised a right second molar, a lower second incisor, upper first incisor, upper canine, lower canine, and a lower second incisor. Our sample of in situ teeth comprised a lower canine, a lower third molar, an upper second molar, and a lower first molar. Microremains were recovered in all Neanderthal dental calculus samples, but there was major variation in the numbers and classes present. The plant microremain assemblages found on the Vindija samples is considerably more diverse than what was reported in the previous studies of Neanderthal calculus by having numerous non-starch and phytolith microremains (Hardy et al., 2012; Henry et al., 2012, 2014).

The highest numbers of microremains were found in Vindija dental calculus samples (SOM Table S1). Fifteen starches (type 15) displayed a lenticular cross-section, circular or subcircular plane view, a hilum exhibiting a thin line, and distinctive surface dimples and lamellae, clearly representing starches from Triticeae grass seeds (Fig. 4). They exhibited some damage and were isolated and clearly have a different origin than non-damaged Triticeae on the wolf sample (type 20). Although grass leaf microremains may arise from non-edible resources such as bedding, this seems unlikely to be the case for grass seeds.

Two of the starches (type 8) are likely to derive from a legume, based on their characteristics: circular, oval or ovoid shape, the presence of lamellae, and the characteristic longitudinal cleft fissure. We have observed these traits in peas (Pisum sp.), vetches (Vicia sp.), and vetchlings (Lathyrus sp.). Three other starches (Fig. 4; type 12 in SOM Table S2) displayed the size, highly faceted surface and polyhedral shape consistent with those of starches from hard endosperm not from Triticeae or legumes (Eliasson and Larsson, 1993). Plants that produce this starch morphology include nuts, hard seeds, seeds from grasses not in the Triticeae tribe, and seeds of sedges like Schoenoplectus. Two starches from underground storage organs (USOs) were evident from large elongated shape and highly eccentric polarization crosses. None of these legume, hard endosperm, or underground storage organ starches had specific enough morphological characteristics to classify them to a specific genus. The remaining starches fall into nine groupings, probably reflecting several taxa, but due to starch damage, redundant types and a limited reference collection, they cannot be identified. Five starch types also found in Neanderthal samples were also found in cave bear samples, but these were nondiagnostic types and thus do not necessarily represent the same taxa.

We recovered phytoliths from the Vindija dental calculus samples from dicot and monocots (SOM Table S1). Phytolith production between the two categories varies from 80:1 to 20:1 (Tsartsidou et al., 2007), while the ratios of monocot to dicot in our sample of Vindija Neanderthal dental calculus vary from $5: 1$ to $0.67: 1$, which suggests an abundance of dicot types such as fruits, nuts and leaves rather than grasses and sedges. Twenty-five spores were found, representing approximately five types of fungus. However, these are nondiagnostic and could represent mushroom-bearing higher fungi or lower fungi such as molds. Pollen was rare and only one Betulaceae pollen was found. Ten unsilicified plant tissue fragments were recovered, two reflecting grass and one an unspecific monocot, but others were indeterminate. Phytoliths were classed into $C_{3}$ Poaceae, Poaceae, monocot, dicot or dicot leaf, while starches were classified into Triticeae, legume, USO, non-Triticeae/legume endosperm starch or a variety of unidentified types. Absolute minimum botanical units varied from 0 to 10 (Table 3; SOM Table S1).

Grotta Guattari and Grotta Fossellone We examined the calculus from the right lower third molar of Grotta Guattari II and the lower first molars (right and left), and a lower second incisor of Grotta Guattari III. Calculus samples from the five teeth from Grotta Guattari produced high numbers of microremains and microremain types. A total of 151 microremains were found in the dental calculus of the five teeth (SOM Table S1). Phytoliths and starches were classified into a similar, but lesser number of minimum botanical units as Vindija. Absolute minimum botanical units varied from 1 to 7 (Table 3; SOM Text S1).

Starch grains were found on four of the five teeth and totaled 69 grains. Six starches found still surrounded by cell walls were elongate ovoid in plane-view and oval in cross-section, with an eccentric polarization cross, all characteristics matching Lilium type starches (Fig. 4; SOM Table S1). One starch clearly represented a Triticeae grass seed starch. Further evidence of grass use is evident from intact grass leaf tissue found in one sample. The other detected starches represented five unknown types.

Thirty-nine phytoliths were recovered, 31 of which originated in monocot tissue and eight from dicot plants. Nine short cell rondel phytoliths were identified. One phytolith was a multicellular epidermal jigsaw morphotype, indicating dicot leafy or fruit matter. We also note the presence of a tracheid vessel, which is another dicot marker. 

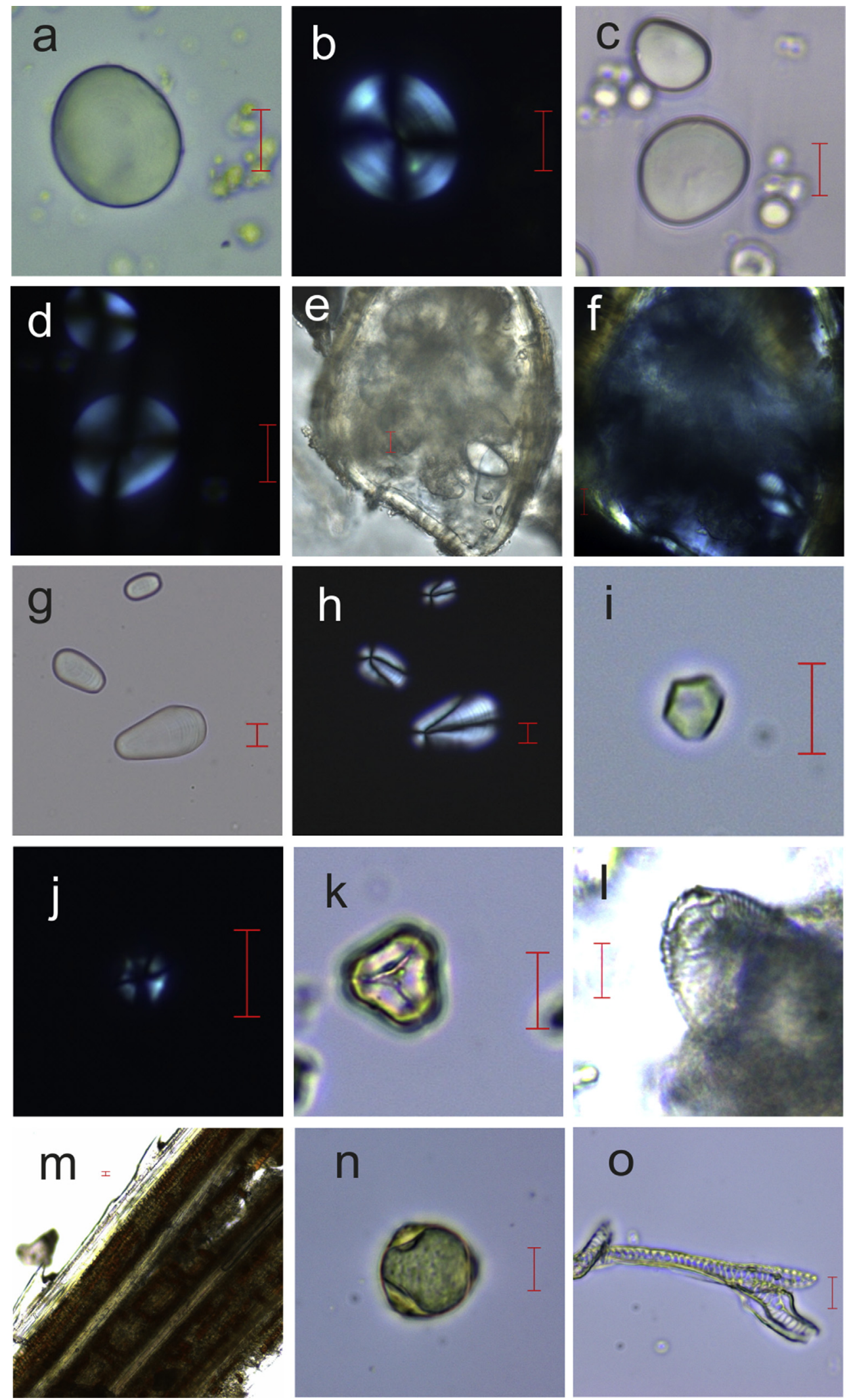

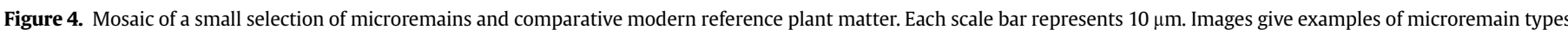

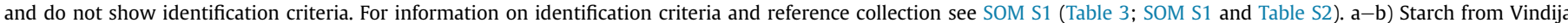

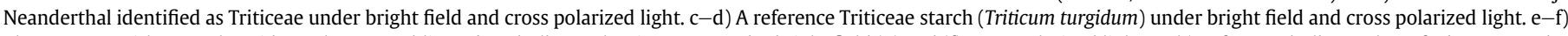

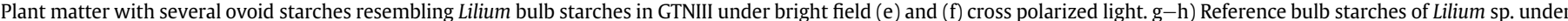

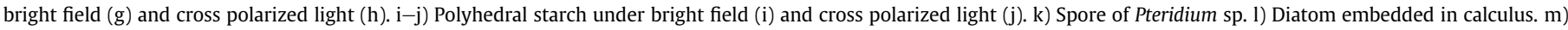
Fragment of grass leaf. n) Triporate Betulaceae pollen. o) Unsilicified tracheid plant tissue. 
Other microremains were numerous. Ten spores were observed, some of which exhibited features that enabled us to identify them as coming from the bracken (Pteridium sp.). We also noted the presence of spores from Nigrospora sp. and fusiform spores, possibly indicative of boletoid fungi. Many bolete fungi are edible and widely consumed, while Nigrospora is a diverse genus of fungi that are mostly agents of decay. Five pollen grains were found including two Betulaceae pollens. In total 14 other cellular plant tissue fragments were noted, including vascular bundles, reflecting plants that entered the mouth. Also recovered were a number of stellate hairs and a pennate diatom.

We sampled dental calculus from the left lower first molar and second molar of Grotta Fossellone III. Eleven starches were found in the two Grotta Fossellone dental calculus samples. These comprised indeterminate starches that cannot yet be matched to reference material. Only one phytolith was found in the assemblage: a rondel phytolith from a grass. Additionally, one piece of monocot and one piece of unidentified plant tissue were found.

Sima de las Palomas del Cabezo Gordo For this study, we sampled dental calculus from six Sima de las Palomas del Cabezo Gordo teeth, including a lower third premolar, a lower canine, a lower third molar, a lower forth premolar, an upper incisor, a lower deciduous forth premolar, and a second molar (catalogue numbers listed in Table 1). We found relatively few microremains in these samples, reflecting the very small amount of dental calculus in each sample. We recovered only five starches and phytoliths, and one diatom. None could be identified to plant taxon. The absolute minimum botanical units varied from 0 to 2 (Table 3; SOM Table S1).

Kalamakia We sampled dental calculus from three Kalamakia teeth: an upper third molar (KAL 3), an upper fourth premolar (KAL 5 ), and an upper second molar (KAL 8). Only a small number of starch grains and phytoliths were found on the three teeth. One phytolith was from a non-monocotyledon. Sixteen possible calcium oxalate forms were found. Calcium oxalate represents consumed plant matter, but it is readily soluble and occurs in most plants, and is therefore not assignable to taxon. Lastly, we found one fragmented sponge spicule. This last microremain likely entered the mouth through drinking water or in stomach contents. The absolute minimum botanical units varied from 1 to 10 (Table 3; SOM Table S1).

\subsection{Dietary flexibility and dietary niche stability}

As we showed earlier using the forager data survey, plant use among living groups is higher in warmer environments, where there is a higher number of taxa within the environment, so we should expect to see a similar pattern among Neanderthals. Using this observation, we predicted that if the breadth of Neanderthal plant use was driven by ecological conditions, then the number of consumed types should be influenced by effective temperature and tree cover. We produced a total MBU and a Menhinick's MBU index comparison of all available samples, including all previously published data and the new samples from this study. Although there is no distinct trend among Neanderthals from different periods or chronologies (Fig. 5; SOM Table S4), there is a possible curvilinear relationship, with microremain numbers increasing with temperature until a peak is reached, at which point the numbers drop again. It is possible this pattern reflects the degradation of starches in the warmest environments (Langejans, 2010).

In our model to test if MBU is predicted by climate and environment, we found no relationship between the minimum botanical units found in calculus and the environmental conditions of the sample, even when accounting for the effects of variation between sites, analyst, age of remains (ka) and the number of microremains

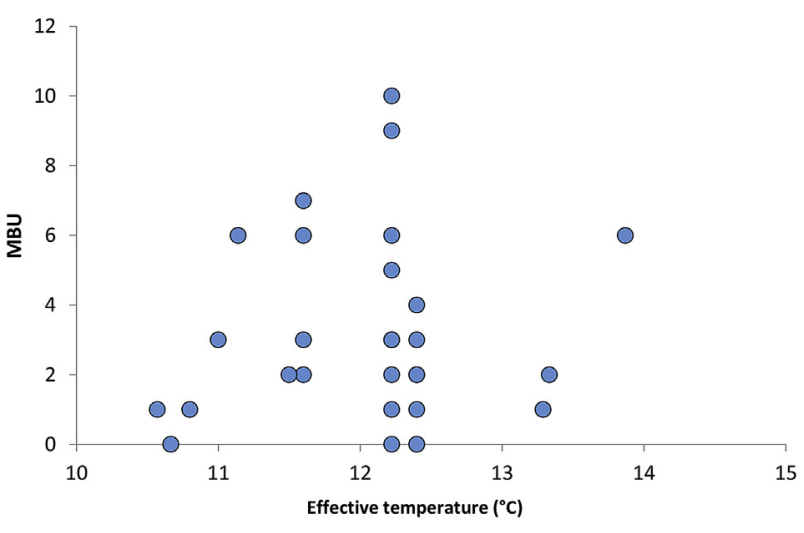

Figure 5. A minimum botanical unit index of the starch and phytoliths from Neanderthal dental calculus shows that warmer climates are not associated with increased diversity. Samples are from Neanderthal remains presented in this study, as well as Salazar-García et al. (2013) and Henry et al. (2014). Each dot represents an individual sample.

in a sample. More specifically, an increase in temperature did not lead to an increase in the number of plants represented in dental calculus and younger sites did not show an increase in the number of plants represented in dental calculus $\left(\chi^{2}=4.251, \mathrm{df}=3\right.$, $p=0.235$; SOM Table S4). Even in the alternative model, which assumed bones in Vindija Cave layer G1 are older than thought and derive from $\mathrm{G} 3$, there was still no relationship $\left(\chi^{2}=4.335, \mathrm{df}=3\right.$, $p=0.227$; SOM Table S4).

It is possible that we are not picking up on all of the variation in microremains because we were able to collect calculus from only one or two individuals at some sites. To test for sample size effects, we performed a resampling test, in which, for each population, we downsampled by choosing one individual randomly 1500 times (given that our smallest population was represented by one individual). This resampling provided a distribution of the average number of microremains for each population. In an ideal case, the distribution for each population would have been significantly different from the other populations (SOM Table S5). However, our pairwise tests failed to indicate differences in many of the pairwise comparisons of the population distribution.

\section{Discussion}

Microscopy revealed starch and phytoliths in most samples, but many samples were highly variable. However, the origin of much of the data's variability cannot be inferred, and could be due to the stochastic nature of the dental calculus dietary record or insufficient sample size. The variable results from calculus samples from the same individuals or even the same tooth support this (Vja-20, 21a and 21b). Due to this, the dental calculus record probably more accurately reflects group diet than individual diet. The development of a novel metric (minimum botanical unit) in this study has helped to overcome some of this variability. Minimum botanical units proved to be a useful means to measure the lowest possible number of taxa represented. We found this metric could be used as a total or as part of a Menhinick's index.

Figure 3, SOM Fig. S1 and SOM Table S1 show that many dental calculus samples from Grotta Fossellone, Sima de las Palomas del Cabezo Gordo and Kalamakia yielded few microremains. Previous work that established baselines with chimpanzee (Power et al., 2015b) and living human (Leonard et al., 2015) populations indicates that this stochastic pattern is normal. These studies emphasize that we have not recovered information on the majority 
of consumed plants. These studies also indicate that, although plants are undoubtedly introduced to the oral cavity through nondietary behaviors such as the inhalation or chewing of plants, these only comprise a modest component of microremain assemblages.

With these findings, we are able to show that Neanderthals in warmer environments who had better access to plant resources might not have necessarily used a far broader range of plant foods, and in some cases, they show less diversity than cool climate ones. However, we are cautious about these findings, as our ability to detect ecogeographical variation may be limited by the range of habitats included or sample size. Also, it is possible that plant remains such as starches are underrepresented in samples from warmer environments due to worse taphonomic conditions (Smith et al., 2001; Langejans, 2010). However, the phytoliths follow a similar pattern, despite being insensitive to temperature, suggesting that the pattern could be due to dietary, instead of taphonomic, trends. Our results on microremain diversity do not negate occlusal dental wear findings that link tree cover to plant use, as occlusal wear approximates only classes of the total diet and not its composition. Pleistocene plant foods likely reflect forest type (Mediterranean or Boreal) far more than tree cover alone. Open and mixed environments have less primary biomass than closed canopy environments, but they may offer significantly more edible plant biomass, as much of the biomass in forests consists of tree trunks, and is thus unavailable to hominin consumers (Odum, 1975). Pleistocene aridity may also have encouraged plant use; among recent foragers at a given latitude, plant consumption usually increased in more open environments, largely because aquatic animal foods are less available in these dryer habitats (Keeley, 1992).

The plants used indicate how Neanderthals sourced nutrition from their environment. We find evidence of the use of grass seeds, true lily tubers, legumes and other starchy plants that leave no taxon-attributable types. Other microremain types included pollen and spores. Spores from Guattari III suggest interaction with fungi but these spores are too rare to ascertain the presence of deliberate use of fungi, such as the consumption of mushrooms (Power et al., 2015a). Not all recovered microremains reflect intentionally consumed food. Recovery of Betulaceae pollen and bracken spores may highlight use of birch or hazel and bracken, but, as these particles are excellent dispersers, they probably simply reflect characteristics of the suspensions and aerosols in the Pleistocene airborne environment. Other rare microremains, such as diatoms and sponge spicules, were probably introduced through drinking water or the consumption of animal stomach contents.

Some of the types that we were able to identify tell us about Neanderthal dietary behavior. In particular, many of the microremains come from foods that are often considered low-ranked, like grass seeds and tubers (Simms, 1985; Kelly, 1995). Grass seeds used at Vindija and at Grotte Guattari demonstrate an investment in a low-rank plant food in cool habitats of the northern Balkans and coastal Italy. The use of grass seeds is often linked to terminal Pleistocene Southwest Asian foragers, who invested in broad spectrum diets because grass seeds are usually costly to harvest and prepare for consumption (Simms, 1985). On the other hand, there is abundant evidence that groups like the Vindija Neanderthals were big game hunters and that energetic contribution from plants is not likely to have rivaled that of meat. Grass seeds are widely used by recent foragers in warm and cool environments (Lothrop, 1928; Simms, 1985; Harlan, 1989; Brand-Miller and Holt, 1998). Middle Paleolithic foragers probably only used grass seed as a limited component of the broader plant diet as this resource offers limited nutritional return (Simms, 1985). This is the pattern observed in Upper Paleolithic human foragers of Southwest Asia, where grass use is most prominent (Savard et al., 2006; Rosen, 2010).
It is unclear if Neanderthals gradually used a more diverse array of plants, alongside the modest increase in Neanderthal population from 70 ka onwards (Foley and Lahr, 2003; van Andel and Davies, 2003; Speth and Clark, 2006). If a chronological trend in vegetal dietary breadth is absent, it agrees with the lack of a trend in their predation niche before $55 \mathrm{ka}$. Although we cannot test if Neanderthal vegetal dietary breadth diverged from an overwhelmingly dominant hunting economy, they did use plant foods. While the exploitation of hard-to-catch game necessitated a costly increase in technology, plants can often be harvested and processed without the investment in technology. Although this may contradict conventional expectations of glacial period foragers in Central Europe, the cold temperatures of Pleistocene Eurasia may mislead us on the ecological productivity of this region. The apparent patterns are better explained by decoupling seed and nut use from the dietary expectations of the traditionally defined 'broad spectrum revolution'. Seed and nut use may have been important foods throughout human evolution (Hockett and Haws, 2003; Revedin et al., 2010; Crittenden and Schnorr, 2017). Additionally, taxonomic diversity in diet is just one way in which diet can intensify due to demographic packing (population increase). Diet could intensify with new hunting techniques and more elaborate processing, detoxification and cooking (Wollstonecroft, 2011). Although an expanding plant food niche may be a sign of demographic packing its presence need not signify a total investment in complex foraging/broad spectrum foraging if such plant exploitation was possible without costly plant harvesting and processing technology (Hockett and Haws, 2003). Non-intensive use of these plants was possible with the technology available to Neanderthals.

Neanderthals could have reduced their processing costs by making use of caches of USOs and seeds, such as rodent stores, and by choosing to harvest the plants during seasons when they were easiest to prepare. The raiding of rodent stores requires little technology, though it often requires considerable ecological knowledge (Jones, 2009). For example, Siberian peoples raided rodent stores to obtain Lilium tubers all year round (Ståhlberg and Svanberg, 2010, 2012), but they had to be able to discern edible tubers from toxic USOs. Neanderthals' ecological knowledge may have also been useful for the consumption of grass seeds. As Neanderthals exhibit no evidence of plant processing or food storage, we propose that Neanderthals collected these seeds without laborious and expensive processing costs. One of the few ways this is possible is by plucking green grain from spikelets before they ripen and harden (Rosner, 2011). Unlike ripe grain, green grain requires no grinding or pulverizing and may be consumed once dehusked, which can be done by hand. Green grain starch granules are smaller than those of ripe grain, but they share most morphological characteristics and are likely to be identified as coming from grass seeds with our methodology (Evers, 1971). Green grain is a resource that is available only in a narrow window before the grain ripens into a hard dry grain (Rosner, 2011). This purported collection of green grain would be suggestive of precise seasonally-organized Neanderthal foraging. Unfortunately, there are insufficient data to reconstruct a seasonal round of plant food gathering, but gathering during the spring is evident.

\section{Conclusions}

The assemblages present evidence of Neanderthal use of plant as foods and complement our understanding of Neanderthal subsistence. This suggests that plant-harvesting strategies existed alongside their medium and large game hunting economy. Processing requirements of plant foods are often a limiting factor in their use (Kuhn and Stiner, 2006). Identifying the processes used to prepare or cook plant foods in different environments would likely 
reveal trends in how Neanderthals adapted to different diets and why they were replaced by Upper Paleolithic peoples. The ability of Neanderthals to anaerobically combust birch bark for tar manufacture hints that sophisticated heat-based food processing may have been available (Koller et al., 2001). Unfortunately, at this point we cannot survey food processing with our microbotanical dataset or the archaeological record as a whole.

Plant foods were likely valued for their micro- or macronutrient profiles rather than caloric energy alone. Hominin physiology limits the total dietary protein intake, impeding an absolute reliance on protein-rich foods such as terrestrial mammals (Cordain et al., 2000; Speth, 2010; Hockett, 2012). Recent foragers have avoided the effects of protein overconsumption by incorporating other macronutrients into their diet. Evidence from recent foragers worldwide suggests sourcing animal fat was a preeminent strategy for offsetting risk of protein poisoning (Speth and Spielmann, 1983; Cordain et al., 2000). However, obtaining concentrated sources of animal fat from a diet of terrestrial ungulates may not have always been possible. Triticeae, Fabaceae and Liliaceae offer rich sources of carbohydrates that may have offset the problems of lean protein consumption.

The incorporation of diverse plant foods, including those with low- or middle-ranking returns into the human diet, probably predates Neanderthal diets and has a long history in the human lineage, and it is likely that such diets persisted throughout hominin evolution mediated by energetic ecological necessity and labor availability. Similarly, resource depletion-driven subsistence change may have occurred at many points in hominin evolution in different food classes, as it is observed in present day chimpanzees, where increases in chimpanzee populations have been linked to increased use of low ranked prey (Watts and Mitani, 2015).

Regarding Neanderthal subsistence, our model also finds no indication that plant use was confined to certain parts of their range; from the warm Mediterranean Basin to the cool habitats of Central Europe. Although microremains preservation may be biased, it is interesting that we did not find that a more diverse range of plants were consumed in southern areas. Although this may be a product of variability in the dental calculus dietary record, it could also reflect relatively unchanging strategies, stable thanks to their success. While past research has revealed unappreciated variability in Neanderthal animal food use (Stiner, 1994; Speth and Clark, 2006), as a whole, animal food provision centered on large to medium-sized game hunting and thus Neanderthals exhibit lower levels of diversity than early modern human counterparts in Eurasia (Richards et al., 2000, 2001). A large to medium-sized game hunting economy supplemented with plant foods may have evolved as a specialization strategy in response to Eurasian environments (Stiner, 2013). Synthesizing these patterns may imply that specialization was a defining force in Neanderthal ecology.

\section{Acknowledgments}

The Max Planck Society provided financial support. We thank Dejana Brajkovic, Jadranka Lenardić, Ivan Gusic, Ivor Karavanić, Philip Nigst, Fred Smith, Tamara Dogandzic and Raffaele Sardella for sampling support and helping with archaeological interpretation. We are grateful to Roger Mundry and Colleen Stephens for statistical support. We thank Pat O'Reilly for mycological advice. We are also thankful to Antje Hutschenreuther, Simone Schmidt, Thomas Büdel and Joerg Watzke for laboratory support, Kathryn Fitzsimmons for climate history help, Karen Ruebens for GIS advice, Paschal Verdin, Sanjay Eksambekar, Linda Perry and Marco Madella for thoughts on microremain identification, and finally Dave Pollard, Robert Foley, and William Davies for advice on using Stage 3 Project data.

\section{Supplementary Online Material}

Supplementary online material related to this article can be found at https://doi.org/10.1016/j.jhevol.2018.02.009.

\section{References}

Ager, T.A., Ager, L.P., 1980. Ethnobotany of the Eskimos of Nelson Island, Alaska. Arctic Anthropology 17, 26-48.

Aiello, L.C., Wheeler, P., 1995. The expensive-tissue hypothesis: the brain and the digestive system in human and primate evolution. Current Anthropology 36, $199-221$.

Bailey, H.P., 1960. A method of determining the warmth and temperateness of climate. Geografiska Annaler 42, 1-16.

Barton, R.N.E., Currant, A.P., Fernández-Jalvo, Y., Finlayson, J.C., Goldberg, P., MacPhail, R., Pettitt, P.B., Stringer, C.B., 1999. Gibraltar Neanderthals and results of recent excavations in Gorham's, Vanguard and Ibex Caves. Antiquity 73, $13-23$.

Bates, D., Maechler, M., Bolker, B., 2013. Ime4: Linear mixed-effects models using S4 classes. R package version 0.999999-2.999999.

Berihuete-Azorín, M., 2013. First archaeobotanical approach to plant use among Selknam hunter-gatherers (Tierra del Fuego, Argentina). Archaeological and Anthropological Sciences 5, 255-266.

Binford, L.R., 1980. Willow smoke and dogs' tails: Hunter-gatherer settlement systems and archaeological site formation. American Antiquity 45, 4-20.

Binford, L.R., 2001. Constructing Frames of Reference: An Analytical Method for Archaeological Theory Building Using Hunter-Gatherer and Environmental Data Sets. University of California Press, Berkeley.

Binford, L.R., Johnson, A.L., 2006. Program for calculating environmental and hunter-gatherer frames of reference (ENVCALC2). Java Version, August.

Blasco, R., Fernández Peris, J., 2009. Middle Pleistocene bird consumption at Level XI of Bolomor Cave (Valencia, Spain). Journal of Archaeological Science 36, 2213-2223.

Blasco, R., Fernández Peris, J., 2012. A uniquely broad spectrum diet during the Middle Pleistocene at Bolomor Cave (Valencia, Spain). Quaternary International 252, 16-31.

Bocherens, H., Drucker, D.G., Bonjean, D., Bridault, A., Conard, N.J., Cupillard, C., Germonpré, M., Höneisen, M., Münzel, S.C., Napierala, H., Patou-Mathis, M., Stephan, E., Uerpmann, H.-P., Ziegler, R., 2011. Isotopic evidence for dietary ecology of cave lion (Panthera spelaea) in North-Western Europe: Prey choice, competition and implications for extinction. Quaternary International 245, 249-261.

Brand-Miller, J.C., Holt, S.H., 1998. Australian aboriginal plant foods: a consideration of their nutritional composition and health implications. Nutrition Research Reviews 11, 5-23.

Buck, L.T., Stringer, C.B., 2014. Having the stomach for it: a contribution to Neanderthal diets? Quaternary Science Reviews 96, 161-167.

Cabanes, D., Shahack-Gross, R., 2015. Understanding fossil phytolith preservation: The role of partial dissolution in paleoecology and archaeology. PLoS One 10, e0125532.

Castellano, S., Parra, G., Sánchez-Quinto, F.A., Racimo, F., Kuhlwilm, M., Kircher, M., Sawyer, S., Fu, Q., Heinze, A., Nickel, B., Dabney, J., Siebauer, M., White, L., Burbano, H.A., Renaud, G., Stenzel, U., Lalueza-Fox, C., de la Rasilla, M., Rosas, A., Rudan, P., Brajković, D., Kucan, Ž., Gušic, I., Shunkov, M.V., Derevianko, A.P. Viola, B., Meyer, M., Kelso, J., Andrés, A.M., Pääbo, S., 2014. Patterns of coding variation in the complete exomes of three Neandertals. Proceedings of the National Academy of Sciences USA 111, 6666-6671.

Clark, C., 2012. Inuit ethnobotany and ethnoecology in Nunavik and Nunatsiavut, northeastern Canada. Masters dissertation, Université de Montréal.

Conard, N.J., Kitagawa, K., Krönneck, P., Bohme, M., Munzel, S.C., 2011. The importance of fish, fowl and small mammals in the Paleolithic diet of the Swabian Jura, Southwestern Germany. In: Clark, J.L., Speth, J.D. (Eds.), Zooarchaeology and Modern Human Origins: Human Hunting Behavior during the Later Pleistocene. Springer Science+Business, Dordrecht, pp. 173-190.

Cordain, L., Miller, J.B., Eaton, S.B., Mann, N., Holt, S.H., Speth, J.D., 2000. Plantanimal subsistence ratios and macronutrient energy estimations in worldwide hunter-gatherer diets. The American Journal of Clinical Nutrition 71, 682-692.

Cortés-Sánchez, M., Morales-Muñiz, A., Simón-Vallejo, M.D., Lozano-Francisco, M.C., Vera-Peláez, J.L., Finlayson, C., Rodríguez-Vidal, J., Delgado-Huertas, A., JiménezEspejo, F.J., Martínez-Ruiz, F., Martínez-Aguirre, M.A., Pascual-Granged, A.J., Bergadà-Zapata, M.M., Gibaja-Bao, J.F., Riquelme-Cantal, J.A., López-Sáez, J.A., Rodrigo-Gámiz, M., Sakai, S., Sugisaki, S., Finlayson, G., Fa, D.A., Bicho, N.F., 2011. Earliest known use of marine resources by Neanderthals. PLoS One 6, e24026.

Crittenden, A.N., Schnorr, S.L., 2017. Current views on hunter-gatherer nutrition and the evolution of the human diet. American Journal of Physiscal Anthropology 163 S63, 84-109.

Crowther, A., Haslam, M., Oakden, N., Walde, D., Mercader, J., 2014. Documenting contamination in ancient starch laboratories. Journal of Archaeological Science 49, 90-104.

Demidenko, E., 2007. Sample size determination for logistic regression revisited. Statistics in Medicine 26, 3385-3397. 
El Zaatari, S., Grine, F.E., Ungar, P.S., Hublin, J.-J., 2011. Ecogeographic variation in Neandertal dietary habits: evidence from occlusal molar microwear texture analysis. Journal of Human Evolution 61, 411-424.

Eliasson, A.C., Larsson, K., 1993. Cereals in Breadmaking: A Molecular Colloidal Approach. CRC Press, New York.

Evers, A.D., 1971. Scanning electron microscopy of wheat starch. III. Granule development in the endosperm. Starch - Stärke 5, 157-192.

Faul, F., Erdfelder, E., Buchner, A., Lang, A.-G., 2009. Statistical power analyses using G*Power 3.1: Tests for correlation and regression analyses. Behavior Research Methods 41, 1149-1160.

Fiorenza, L., 2015. Reconstructing diet and behaviour of Neanderthals from Central Italy through dental macrowear analysis. Journal of Anthropological Sciences 93, 1-15.

Fiorenza, L., Benazzi, S., Tausch, J., Kullmer, O., Bromage, T.G., Schrenk, F., 2011. Molar macrowear reveals Neanderthal eco-geographic dietary variation. PLoS One 6, e14769.

Fiorenza, L., Benazzi, S., Henry, A.G., Salazar-García, D.C., Blasco, R., Picin, A., Wroe, S., Kullmer, O., 2015. To meat or not to meat? New perspectives on Neanderthal ecology. American Journal of Physical Anthropology 156(S59), 43-71.

Foley, R., Lahr, M.M., 2003. On stony ground: Lithic technology, human evolution, and the emergence of culture. Evolutionary Anthropology 12, 109-122.

Gale, R., Carruthers, W., 2000. Charcoal and charred seed remains from Middle Palaeolithic levels at Gorham's and Vanguard Caves. In: Stringer, C.B., Barton, R.N.E., Finlayson, J.C. (Eds.), Neanderthals on the Edge. Oxbow Books, Oxford, pp. 207-210.

Gaudzinski-Windheuser, S., Roebroeks, W., 2011. On Neanderthal subsistence in last Interglacial forested environments in northern Europe. In: Conard, N.J., Richter, J. (Eds.), Neanderthal Lifeways, Subsistence and Technology: One Hundred Fifty Years of Neanderthal Study. Springer Science \& Business Media, Dordrecht, pp. 61-71.

Grayson, D.K., Delpech, F., 1998. Changing diet breadth in the Early Upper Palaeolithic of Southwestern France. Journal of Archaeological Science 25, 1119-1129.

Grine, F.E., 1986. Dental evidence for dietary differences in Australopithecus and Paranthropus: a quantitative analysis of permanent molar microwear. Journal of Human Evolution 15, 783-822.

Hardy, B.L., 2010. Climatic variability and plant food distribution in Pleistocene Europe: Implications for Neanderthal diet and subsistence. Quaternary Science Reviews 29, 662-679.

Hardy, B.L., Moncel, M.-H., Daujeard, C., Fernandes, P., Béarez, P., Desclaux, E., Chacon Navarro, M.G., Puaud, S., Gallotti, R., 2013. Impossible Neanderthals? Making string, throwing projectiles and catching small game during Marine Isotope Stage 4 (Abri du Maras, France). Quaternary Science Reviews 82, 23-40.

Hardy, K., Buckley, S., Collins, M.J., Estalrrich, A., Brothwell, D., Copeland, L., GarcíaTabernero, A., García-Vargas, S., de la Rasilla, M., Lalueza-Fox, C., Huguet, R., Bastir, M., Santamaría, D., Madella, M., Wilson, J., Cortés, A.F., Rosas, A., 2012. Neanderthal medics? Evidence for food, cooking, and medicinal plants entrapped in dental calculus. Naturwissenschaften 99, 617-626.

Harlan, J.R., 1989. Wild-grass seed harvesting in the Sahara and sub-Sahara of Africa. In: Harris, D.R., Hillman, G.C. (Eds.), Foraging and Farming: The Evolution of Plant Exploitation. Unwin Hyman, London, pp. 79-98.

Harvati, K., Darlas, A., Bailey, S.E., Rein, T.R., El Zaatari, S., Fiorenza, L., Kullmer, O., Psathi, E., 2013. New Neanderthal remains from Mani peninsula, Southern Greece: the Kalamakia Middle Paleolithic cave site. Journal of Human Evolution 64, 486-499.

Hattori, S., 2006. Utilization of Marantaceae plants by the Baka hunter-gatherers in southeastern Cameroon. African Study Monographs 33, 29-48.

Henry, A.G., 2014. Formation and taphonomic processes affecting starch grains. In: Marston, J.M., Guedes, J.D., Warinner, C. (Eds.), Current Methods in Paleoethnobotany. University of Colorado Press, Boulder, pp. 35-50.

Henry, A.G., Brooks, A.S., Piperno, D.R., 2011. Microfossils in calculus demonstrate consumption of plants and cooked foods in Neanderthal diets (Shanidar III, Iraq; Spy I and II, Belgium). Proceedings of the National Academy of Sciences USA 108, 486-491.

Henry, A.G., Hudson, H.F., Piperno, D.R., 2009. Changes in starch grain morphologies from cooking. Journal of Archaeological Science 36, 915-922.

Henry, A.G., Ungar, P.S., Passey, B.H., Sponheimer, M., Rossouw, L., Bamford, M., Sandberg, P., de Ruiter, D.J., Berger, L., 2012. The diet of Australopithecus sediba. Nature 487, 90-93.

Henry, A.G., Brooks, A.S., Piperno, D.R., 2014. Plant foods and the dietary ecology of Neanderthals and early modern humans. Journal of Human Evolution 69, 44-54.

Hijmans, R.J., Cameron, S.E., Parra, J.L., Jones, P.G., Jarvis, A., 2005. Very high resolution interpolated climate surfaces for global land areas. International Journal of Climatology 25, 1965-1978.

Hockett, B.S., 2012. The consequences of Middle Paleolithic diets on pregnant Neanderthal women. Quaternary International 264, 78-82.

Hockett, B.S., Haws, J.A., 2003. Nutritional ecology and diachronic trends in Paleolithic diet and health. Evolutionary Anthropology 12, 211-216.

Hockett, B.S., Haws, J.A., 2009. Continuity in animal resource diversity in the Late Pleistocene human diet of Central Portugal. Before Farming 2009, 1-14.

Ichikawa, M., Terashima, H., 1996. Cultural diversity in the use of plants by Mbuti hunter-gatherers in northeastern Zaire: an ethnobotanical approach. In: Kent, S. (Ed.), Cultural Diversity among Twentieth-Centuary Foragers. Cambridge University Press, Cambridge, pp. 276-293.
International Code for Starch Nomenclature (ICSN), 2011. The International Code for Starch Nomenclature. http://fossilfarm.org/ICSN/Code.html. (Accessed March 1, 2015).

Jones, M., 2009. Moving North: Archaeobotanical evidence for plant diet in Middle and Upper Paleolithic Europe. In: Hublin, J.-J., Richards, M.P. (Eds.), The Evolution of Hominin Diets: Integrating Approaches to the Study of Palaeolithic Subsistence. Springer, Dordrecht, pp. 171-180.

Keeley, L.H., 1992. The use of plant foods among hunter-gatherers: A cross-cultural survey. In: Anderson, P.C. (Ed.), Préhistoire de l'Agriculture. Nouvelles Approches Expérimentales et Ethnographiques. National Center for Scientific Research, Paris, pp. 29-38.

Kelly, R.L., 1995. The Foraging Spectrum: Diversity in Hunter-Gatherer Lifeways. Eliot Werner Publications, New York.

Kirby, K.R., Gray, R.D., Greenhill, S.J., Jordan, F.M., Gomes-Ng, S., Bibiko, H.-J., Blasi, D.E., Botero, C.A., Bowern, C., Ember, C.R., Leehr, D., Low, B.S., McCarter, J., Divale, W., Gavin, M.C., Kirby, K.R., Gray, R.D., Greenhill, S.J., Jordan, F.M., GomesNg, S., Bibiko, H.-J., Blasi, D.E., Botero, C.A., Bowern, C., Ember, C.R., Leehr, D., Low, B.S., McCarter, J., Divale, W., Gavin, M.C., 2016. D-PLACE: A global database of cultural, linguistic and environmental diversity. PLoS One 11, e0158391.

Koller, J., Baumer, U., Mania, D., 2001. High-tech in the middle Palaeolithic: Neandertal-manufactured pitch identified. Eurasian Journal of Archaeology 4, 385-397.

Kuhn, S.L., Stiner, M.C., 2006. What's a mother to do? The division of labor among Neandertals and modern humans in Eurasia. Current Anthropology 47, 953-981.

Langejans, G.H.J., 2010. Remains of the day-preservation of organic micro-residues on stone tools. Journal of Archaeological Science 37, 971-985.

Langejans, G.H.J., 2011. Discerning use-related micro-residues on tools: testing the multi-stranded approach for archaeological studies. Journal of Archaeological Science 38, 985-1000.

Lee-Thorp, J., Sponheimer, M., 2006. Contributions of biogeochemistry to understanding hominin dietary ecology. Yearbook of Physical Anthropology 43,131-148.

Leonard, C., Vashro, L., O'Connell, J.F., Henry, A.G., 2015. Plant microremains in dental calculus as a record of plant consumption: a test with Twe foragerhorticulturalists. Journal of Archaeological Science: Reports 2, 449-457.

Lev, E., Kislev, M.E., Bar-Yosef, O., 2005. Mousterian vegetal food in Kebara Cave. Mt. Carmel. Journal of Archaeological Science 32, 475-484.

Lothrop, S.K., 1928. The Indians of Tierra del Fuego. Museum of the American Indian, New York.

Lu, T., 2000. The survival of starch residue in a subtropical environment. In: Wallis, D.M., Hart, L.A. (Eds.), Phytolith and Starch Research in the AustralianPacific-Asian Regions: The State of the Art. Pandanus Books, Canberra, pp. 119-126.

Macdonald, K., Roebroeks, W., Verpoorte, A., 2009. An energetics perspective on the Neandertal record. In: Hublin, J.-J., Richards, M.P. (Eds.), The Evolution of Hominin Diets: Integrating Approaches to the Study of Palaeolithic Subsistence. Springer, Dordrecht, pp. 211-220.

Madella, M., Alexandre, A., Ball, T., 2005. International Code for Phytolith Nomenclature 1.0. Annals of Botany 96, 253-260.

Madella, M., Jones, M.K., Goldberg, P., Goren, Y., Hovers, E., 2002. The exploitation of plant resources by Neanderthals in Amud Cave (Israel): The evidence from phytolith studies. Journal of Archaeological Science 29, 703-719.

Madella, M., Lancelotti, C., 2012. Taphonomy and phytoliths: A user manual. Quaternary International 275, 76-83.

Magurran, A.E., 2004. Measuring Biological Diversity. Blackwell Publishing, Oxford.

Marean, C.W., 1997. Hunter-gatherer foraging strategies in tropical grasslands: model building and testing in the East African Middle and Later Stone Age. Journal of Anthropological Archaeology 16, 189-225.

Marlowe, F.W., 2010. The Hadza: Hunter-Gatherers of Tanzania. University of California Press, London.

Matsutani, A., 1987. Plant remains from the 1984 excavations at Douara Cave. In: Akazawa, T., Sakaguchi, Y. (Eds.), Paleolithic Site of Douara Cave and Paleogeography of Palmyra Basin in Syria: Part IV: 1984 Excavations. The University of Tokyo Press, Tokyo, pp. 117-122.

Meriggi, A., Rosa, P., Brangi, A., Matteucci, C., 1991. Habitat use and diet of the wolf in northern Italy. Acta Theriologica 36, 141-151.

Murie, A., 1944. The Wolves of Mount McKinley. Fauna of the National Parks of the United States. Fauna Series; no. 5. U.S. Government Printing Office, Washington.

O'Connell, J.F., 2006. How did modern humans displace Neanderthals? Insights from hunter-gatherer ethnography and archaeology. In: Conard, N.J. (Ed.), When Neanderthals and Modern Humans Met. Kerns Verlag, Tübingen, pp. 43-64.

O'Connell, J.F., Latz, P.K., Barnett, P., 1983. Traditional and modern plant use among the Alyawara of central Australia. Economic Botany 37, 80-109.

Odum, E.P. (Ed.), 1975. Ecology, second ed. Holt, Rinehart and Winston, New York.

Owens, F.N., Zinn, R.A., Kim, Y.K., 1986. Limits to starch digestion in the ruminant small intestine. Journal of Animal Science 63, 1634-1648.

Pacher, M., Stuart, A.J., 2009. Extinction chronology and palaeobiology of the cave bear (Ursus spelaeus). Boreas 38, 189-206.

Peng, M., Gao, M., Abdel-Aal, E.S.M., Hucl, P., Chibbar, R.N., 1999. Separation and characterization of A- and B-type starch granules in wheat endosperm. Cereal Chemistry 76, 375-379.

Power, R.C., Salazar-García, D.C., Wittig, R.M., Henry, A.G., 2014. Assessing use and suitability of scanning electron microscopy in the analysis of micro remains in dental calculus. Journal of Archaeological Science 49, 160-169. 
Power, R.C., Salazar-García, D.C., Straus, L.G., González Morales, M.R., Henry, A.G., 2015a. Microremains from El Mirón Cave human dental calculus suggest a mixed plant-animal subsistence economy during the Magdalenian in Northern Iberia. Journal of Archaeological Science 60, 39-46.

Power, R.C., Salazar-García, D.C., Wittig, R.M., Freiberg, M., Henry, A.G., 2015b. Dental calculus evidence of Taï Forest chimpanzee plant consumption and life history transitions. Scientific Reports 5, 15161.

Revedin, A., Aranguren, B., Becattini, R., Longo, L., Marconi, E., Lippi, M.M., Skakun, N., Sinitsyn, A., Spiridonova, E., Svoboda, J., 2010. Thirty thousand-yearold evidence of plant food processing. Proceedings of the National Academy of Sciences USA 107, 18815-18819.

Richards, M.P., Trinkaus, E., 2009. Out of Africa: modern human origins special feature: isotopic evidence for the diets of European Neanderthals and early modern humans. Proceedings of the National Academy of Sciences USA 106 16034-16039.

Richards, M.P., Pettitt, P.B., Trinkaus, E., Smith, F.H., Paunović, M., Karavanić, I., 2000. Neanderthal diet at Vindija and Neanderthal predation: the evidence from stable isotopes. Proceedings of the National Academy of Sciences USA 97, 7663-7666.

Richards, M.P., Pettitt, P.B., Stiner, M.C., Trinkaus, E., 2001. Stable isotope evidence for increasing dietary breadth in the European mid-Upper Paleolithic. Proceedings of the National Academy of Sciences USA 98, 6528-6532.

Rosen, A., 2010. Natufian plant exploitation: Managing risk and stability in an environment of change. Eurasian Prehistory 7, 117-131.

Rosner, A., 2011. Roasting green wheat in Galilee. Gastronomica 11, 60-68.

Rothman, J.M., Van Soest, P.J., Pell, A.N., 2006. Decaying wood is a sodium source for mountain gorillas. Biology Letters 2, 321-324.

Salazar-García, D.C., Power, R.C., Sanchis Serra, A., Villaverde, V., Walker, M.J. Henry, A.G., 2013. Neanderthal diets in central and southeastern Mediterranean Iberia. Quaternary International 318, 3-18.

Sandgathe, D.M., Hayden, B., 2003. Did Neanderthals eat inner bark? Antiquity 77, 709-718.

Savard, M., Nesbitt, M., Jones, M.K., 2006. The role of wild grasses in subsistence and sedentism: new evidence from the northern Fertile Crescent. World Archaeology 38, 179-196.

Simms, S.R., 1985. Acquisition cost and nutritional data on Great Basin resources Journal of California and Great Basin Anthropology 7, 117-126.

Smith, C.I., Chamberlain, A.T., Riley, M.S., Cooper, A., Stringer, C.B., Collins, M.J., 2001 Neanderthal DNA: Not just old but old and cold? Nature 410, 771-772.

Smith, H.H., 1932. Ethnobotany of the Ojibwe Indians. Bulletin of The Public Museum of the City of Milwaukee 4, 327-525.

Speth, J.D., 2010. The Paleoanthropology and Archaeology of Big-Game Hunting: Protein, Fat, or Politics? Springer, New York.

Speth, J.D., Clark, J.L., 2006. Hunting and overhunting in the Levantine Late Middle Palaeolithic. Before Farming 3, 1-42.

Speth, J.D., Spielmann, K.A., 1983. Energy source, protein metabolism, and huntergatherer subsistence strategies. Journal of Anthropological Archaeology 2,1-31.

Ståhlberg, S., Svanberg, I., 2010. Gathering food from rodent nests in Siberia. Journal of Ethnobiology 30, 184-202.

Ståhlberg, S., Svanberg, I., 2012. Gathering dog's tooth violet (Erythronium sibiricum) in Siberia. Journal de la Societé Finno-Ougrienne 91, 349-351.

Stahler, D.R., Smith, D.W., Guernsey, D.S., 2006. Foraging and feeding ecology of the gray wolf (Canis lupus): lessons from Yellowstone National Park, Wyoming, USA. The Journal of Nutrition 136, 1923S-1926S.

Stewart, J.R., 2005. The ecology and adaptation of Neanderthals during the nonanalogue environment of Oxygen Isotope Stage 3. Quaternary International 137, 35-46.

Stiner, M.C., 1994. Honor Among Thieves: a Zooarchaeological Study of Neandertal Ecology. Princeton University Press, Princeton.
Stiner, M.C., 1999. Paleolithic population growth pulses evidenced by small animal exploitation. Science 283, 190-194.

Stiner, M.C., 2001. Thirty years on the "Broad Spectrum Revolution" and Paleolithic demography. Proceedings of the National Academy of Sciences USA 98, 6993-6996.

Stiner, M.C., 2013. An unshakable Middle Paleolithic? Trends versus conservatism in the predatory niche and their social ramifications. Current Anthropology 54, S288-S304.

Stiner, M.C. Kuhn, S.L., 2009. Paleolithic diet and the division of labor in Mediterranean Eurasia. In: Hublin, J.-J., Richards, M.P. (Eds.), The Evolution of Hominin Diets: Integrating Approaches to the Study of Palaeolithic Subsistence. Springer, Dordrecht, pp. 155-168.

Stiner, M.C., Munro, N.D., 2002. Approaches to prehistoric diet breadth, demography, and prey ranking systems in time and space. Journal of Archaeological Method and Theory 9, 181-214.

Stiner, M.C., Munro, N.D., Surovell, T.A., 2000. The tortoise and the hare: small game use, the Broad Spectrum Revolution, and Paleolithic demography. Current Anthropology 41, 39-79.

Stringer, C.B., Finlayson, J.C., Barton, R.N.E., Fernández-Jalvo, Y., Cáceres, I., Sabin, R.C. Rhodes, E.J., Currant, A.P., Rodríguez-Vidal, J. Giles Pacheco, F., Riquelme-Cantal, J.A., 2008. Neanderthal exploitation of marine mammals in Gibraltar. Proceedings of the National Academy of Sciences USA 105, $14319-14324$

Tsartsidou, G., Lev-Yadun, S., Albert, R.M., Miller-Rosen, A., Efstratiou, N., Weiner, S., 2007. The phytolith archaeological record: strengths and weaknesses evaluated based on a quantitative modern reference collection from Greece. Journal of Archaeological Science 34, 1262-1275.

van Andel, T.H., Davies, W., 2003. Neanderthals and Modern Humans in the European Landscape During the Last Glaciation: Archaeological Results of the Stage 3 Project. McDonald Institute for Archaeological Research, Cambridge.

Veltre, D., Pendleton, C., Schively, S., Hay, J., 2006. Aleut Ethnobotany: An Annotated Bibliography. Institute for Circumpolar Health Studies, Anchorage.

Verpoorte, A., 2009. Limiting factors on early modern human dispersals: The human biogeography of late Pleniglacial Europe. Quaternary International 201, 77-85.

Wales, N., 2012. Modeling Neanderthal clothing using ethnographic analogues. Journal of Human Evolution 63, 781-795.

Watts, D.P., Mitani, J.C., 2015. Hunting and prey switching by chimpanzees (Pan troglodytes schweinfurthii) at Ngogo. International Journal of Primatology 36, 728-748.

Weyrich, L.S., Duchene, S., Soubrier, J., Arriola, L., Llamas, B., Breen, J., Morris, A.G., Alt, K.W., Caramelli, D., Dresely, V., Farrell, M., Farrer, A.G., Francken, M., Gully, N., Haak, W. Hardy, K. Harvati, K., Held, P., Holmes, E.C., Kaidonis, J., Lalueza-Fox, C., de la Rasilla, M., Rosas, A., Semal, P., Soltysiak, A., Townsend, G., Usai, D., Wahl, J., Huson, D.H., Dobney, K., Cooper, A., 2017. Neanderthal behaviour, diet, and disease inferred from ancient DNA in dental calculus. Nature 544, 357-361.

Winterhalder, B., Smith, E.A., 2000. Analyzing adaptive strategies: Human behavioral ecology at twenty-five. Evolutionary Anthropology 9, 51-72.

Wißing, C., Rougier, H., Crevecoeur, I., Germonpré, M., Naito, Y.I., Semal, P. Bocherens, H., 2015. Isotopic evidence for dietary ecology of late Neandertals in North-Western Europe. Quaternary International 411, 327-345.

Wollstonecroft, M.M., 2011. Investigating the role of food processing in human evolution: A niche construction approach. Archaeology and Anthropology Sciences 3, 141-150.

Zilhão, J., Angelucci, D.E., Badal-García, E., D'Errico, F., Daniel, F., Dayet, L., Douka, K., Higham, T.F.G. Martínez-Sánchez, M.J. Montes-Bernárdez, R., MurciaMascarós, S., Pérez-Sirvent, C., Roldán-García, C., Vanhaeren, M., Villaverde, V., Wood, R.E., Zapata, J., 2010. Symbolic use of marine shells and mineral pigments by Iberian Neandertals. Proceedings of the National Academy of Sciences USA 107, 1023-1028. 